\title{
1. INTRODUCTION: OBJECTIVES AND RESULTS OF DEEP SEA DRILLING PROJECT LEG 91 AND THE NGENDEI SEISMIC EXPERIMENT, AND EXPLANATORY NOTES FOR VOLUME 91'
}

\author{
Thomas H. Jordan, H. W. Menard, James H. Natland, and John Orcutt, Scripps Institution of Oceanography ${ }^{2}$
}

Leg 91 was dedicated to the deployment of the Marine Seismic System (MSS) at a site in the Southwest $\mathrm{Pa}$ cific Basin, approximately $1000 \mathrm{~km}$ east of the Tonga Trench. The MSS is a downhole seismometer system developed by the Naval Ocean Research and Development Activity (NORDA) and the Defense Advanced Research Projects Agency (DARPA) to monitor regional seismicity in the deep-ocean environment for potential use in verifying compliance with nuclear test-ban treaties. In its Leg 91 configuration, the MSS consisted of four basic components:

(1) a borehole instrument package (BIP) comprising two vertical-component and two horizontal-component seismometers, state-of-health sensors, and related instrumentation;

(2) a bottom processing package (BPP) capable of providing power to the BIP and recording data from it for a 45-day period;

(3) an electromechanical (EM) cable connecting the BIP to the BPP or to on-deck devices; and

(4) an installation, recovery, and reinstallation (IRR) system for deep-water mooring of the MSS.

The MSS deployment strategy was to emplace the BIP in a hole drilled by Glomar Challenger into the basaltic basement that underlies the oceanic sediments, which has several potential advantages over locating seismometers within the sediment column or directly on the seafloor. Ambient seismic noise levels on the seafloor are known to be high, presumably because noise generated by pressure fluctuations within the water column is trapped as evanescent Stoneley waves propagating along the sediment/water interface and as locked modes within the low-rigidity sediment layer (Bradner et al., 1965; Latham and Sutton, 1966, Latham and Nowroozi, 1968). Model calculations involving complete transfer functions for realistic crustal structures indicate that noise levels below the sediment layer should be substantially reduced. Burial also isolates the seismometers from the motions caused by vortex shedding and current fluctuations within the benthic boundary layer, which have been shown to produce noise on ocean bottom seismometers (OBS) with significant cross sections in the water column (Sutton et al., 1980). Therefore, the signal-to-noise ratio for

\footnotetext{
${ }^{1}$ Menard, H. W., Natland, J., Jordan, T. H., Orcutt, J. A., et al., Init. Repts. DSDP, 91: Washington (U.S. Govt. Printing Office).

2 Addresses: (Jordan, Menard) Geological Research Division, Scripps Institution of Oceanography, La Jolla, CA 92093, (Jordan, present address: Department of Earth, Atmospheric, and Planetary Sciences, Massachusetts Institute of Technology, Cambridge, MA 02139); (Natland) Deep Sea Drilling Project (A-031), Scripps Institution of Oceanography, La Jolla, CA 92093; (Orcutt) Institute of Geophysics and Planetary Physics (A-025), Scripps Institution of Oceanography, La Jolla, CA 92093.
}

regional and teleseismic events recorded by the MSS should be significantly better than that attainable by OBSs.

There are other problems attendant to seismic recording on the seafloor that can be mitigated by emplacement of the sensors in hard rock. Seismograms made by relatively massive OBSs resting on sediments of low shear modulus are distorted by coupling resonances and the interactions of the instruments with wave fields in the water column; these distortions can be especially severe on the horizontal components (Sutton et al., 1981; Zelikovitz and Prothero, 1981; Garmany, 1984). Borehole deployment is the most obvious way to reduce the coupling problems and thereby yield vector particle motions that are more easily interpreted in terms of free-field displacements.

In March 1981, a prototype of the BIP was successfully emplaced by the Glomar Challenger during a reoccupation of Deep Sea Drilling Project (DSDP) Hole 395A in the central Atlantic on Leg 78B (Ballard et al., 1984). Approximately $26 \mathrm{hr}$. of vertical-component seismic data were collected via the EM cable by the recording instrumentation on the deck of the Challenger. Comparison of these records with simultaneous observations made by a University of Texas OBS near the hole showed that, in the frequency band $0.2-2 \mathrm{~Hz}$, the downhole ambient noise levels were on the order of 10-30 dB less than those at the seafloor (Adair et al., 1984). Refraction data were also collected (Jacobson et al., 1984). We shall refer to this experiment as MSS ' 81 .

The BIP used in MSS '81 included two short-period, vertical-component seismometers with piezoelectric transducers (Teledyne Geotech model S-750). The design was subsequently modified to comprise two vertical (one primary, one backup) and two horizontal seismometers with orthogonal orientations. Each of the primary sensors was reconfigured with a short-period and midperiod channel.

A full-scale deployment of the MSS, including the upgraded seismometer package, was planned for Leg 88 (July-August 1982) at a site in the northwest Pacific, but operational difficulties prevented the BIP from ever leaving the deck. However, a separate experiment employing a downhole seismometer package designed by the Hawaii Institute of Geophysics (HIG) was successful (Duennebier, Steven, Gettrust, et al., Leg 88 portion of this volume). Several components of the MSS system were used for on-deck recording of the HIG package during the initial phase of its deployment, and this provided useful engineering experience with these components. 
Immediately following Leg 88 , DARPA representatives approached the National Science Foundation and the JOIDES Planning Committee to propose a second attempt for a full-scale MSS development, this time at a site near the Tonga Trench. Glomar Challenger had been scheduled to steam without drilling from Wellington, New Zealand, to Papeete, Tahiti, in early 1983. An agreement was reached to postpone previously planned legs and insert a new leg for the MSS deployment in January-February 1983.

Thus, on comparatively short notice, Leg 91 was staffed and the MSS equipment was shipped from Yokohama, Japan, where Leg 88 had terminated, to Wellington. Glomar Challenger departed Wellington on 16 January, 1983, on a course to the preselected target area.

Meanwhile, a second oceanographic research vessel, Scripps Institution's Melville, was equipped to serve as a shooting ship for the seismic refraction experiment and to deploy OBSs in support of MSS operations. Melville sailed south from Honolulu, Hawaii, on 9 January, 1983, arriving in the target area about $36 \mathrm{hr}$. ahead of Glomar Challenger. A site selection survey was begun immediately and Melville was positioned near a specific drilling target when Glomar Challenger arrived.

This volume documents the drilling and seismic experiments conducted by Glomar Challenger at DSDP Site 595, where the MSS was successfully deployed, and the hydraulic piston coring at Site 596, approximately $8 \mathrm{n}$. mi. west of Site 595. It also discusses the concurrent operations of the Melville, as well as the recovery of the OBS array and the bottom processing package of the MSS by Melville in late March 1983. The two cruises of Melville are formally designated as Benthic Expedition, Legs 4 and 6. These operations and the operations of Glomar Challenger at Site 595 are referred to collectively as the Ngendei Seismic Experiment, named after the Fijian deity of earthquakes and volcanoes.

\section{OBJECTIVES}

Leg 91 had both engineering and scientific objectives. The former centered on the operational testing of the complete MSS system. Because the BIP has a diameter too large ( 8 in.) to pass through the drill string, novel procedures had been developed for its deployment from a specially designed carriage at the end of the string, through a modified version of the DSDP reentry system, into a cased borehole. These procedures were successfully tested on Leg 78B, where a prototype BIP was emplaced in a previously drilled hole. Leg 91, however, was the first full-scale deployment of the MSS into a new borehole. In particular it was the initial sea test of the BPP and IRR subsystems, and the collection of engineering data on the performance of these components was a primary objective of the experiment.

The scientific objectives of seismic experiments were of two principal types: (1) those related to the general problems of assessing and understanding the seismic recording environment of the oceanic crust below the sediments and (2) those pertaining to the specific problems of crustal and upper mantle structure in the southwest Pacific. For questions of the first type, the concurrent operation of MSS and OBS instrumentation is essential. The comparison of noise levels and signals recorded by the downhole sensors with those recorded on the seafloor provides direct observations of the signal-to-noise improvement attainable by the burial of seismometers below the low-rigidity pelagic sediments. Moreover, the detailed comparison of wave forms from common sources such as refraction shots and earthquakes allows one to evaluate the interactions of signals with upper oceanic crustal structure, as well as the problems associated with seismometer coupling. The variation of noise levels and spectral shapes with depth can be used to investigate the modes of noise propagation on the seafloor and to test physical models of noise generation in the ocean basins. The collection of MSS and OBS data sets relevant to these poorly understood problems of the deep-sea seismometric environment was thus a primary objective of the Ngendei Experiment.

The details of the operational plan for the Ngendei Experiment were largely dictated by the second class of scientific objectives, those pertaining to earth structure and regional wave propagation. DARPA's motivation for the MSS program was to establish a capability for monitoring regional seismicity in the deep-water environment, and it was the collection of data to demonstrate this capability that figured prominently in the site selection. The Southwest Pacific Basin is a nearly ideal location for the experiment, because it lies immediately east of the world's most seismically active region, the TongaKermadec subduction zone. Target areas were evaluated on the basis of their distance from the Tonga Trench, water depth, and the documented existence of an adequate sediment thickness to spud in a drill string and stabilize a reentry cone on the seafloor. The site finally selected was located approximately $8^{\circ}$ from the nearest trench seismicity (Fig. 1), a good position from which to observe the seismic signals generated by events within the subduction zone. In particular, the geometry provides the times and amplitudes of waves propagating from intermediate and deep-focus earthquakes needed to constrain elastic and anelastic models of the oceanic upper mantle. The Ngendei Experiment provided a unique opportunity to collect data along such source-receiver paths.

The second major structural study proposed for Leg 91 was a multiple-profile refraction experiment using $\mathrm{Mel}$ ville as the shooting ship, and the MSS and a six-element OBS array as receivers. In addition to generating waveforms for the MSS/OBS comparison, the refraction experiment was designed to provide data for detailed structural studies of the crust and upper mantle in the vicinity of the MSS site. The one-dimensional models derived from these studies are important for assessing the local propagation effects on teleseismic waves and accounting for these effects in the wave-form comparisons. Moreover, the geometry design of the refraction experiment-a star pattern of split profiles with extended lines in two orthogonal directions-permits the study of three-dimensional structure and anisotropic variation of the crust and upper mantle, from which constraints on the tectogenesis of the lithosphere in this old ocean basin can be derived. 


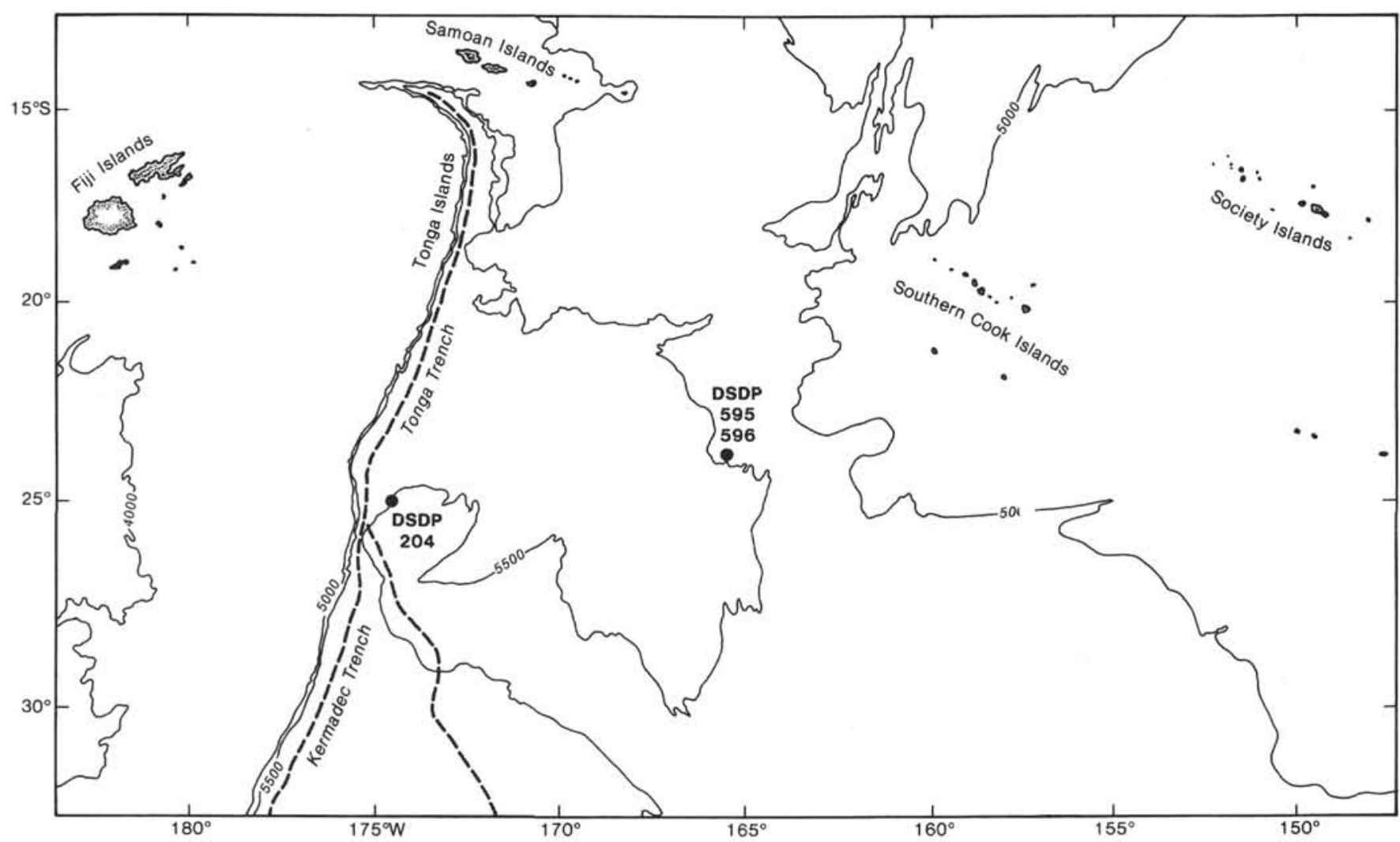

Figure 1. Location of Deep Sea Drilling Project Sites 595 and 596 in the southwest Pacific near the Tonga Trench. Contours in uncorrected meters.

The refraction experiment was scheduled during the on-deck phase of MSS recording, so that we could monitor the signal-to-noise levels of the refraction shots in real time and, using the radio link between the Challenger and Melville, optimize the shot size. In this way, two orthogonal profiles could be extended as far as possible with the limited supply (20 tons) of explosives carried by the Melville, thus permitting us to probe as deeply as possible the lithospheric velocity structure.

In addition to the goals of the seismic experiments, there were a variety of scientific objectives related to the survey work and the drilling. Sites 595 and 596 are located in one of the most poorly studied tracts of seafloor in the world. The magnetic anomaly data collected prior to Leg 91 did not provide a clear indication of the regional orientation of spreading centers and fracture zones, and the bathymetric track lines were too widely spaced to give the details of the structural trends on the seafloor that might be used to infer the original spreading direction in the absence of magnetic anomalies. All we could say with certainty was that the crust of the target area was generated at a rapidly spreading ridge, probably at high southern latitude sometime during the Mesozoic. With Glomar Challenger steaming to the site from the southwest and the Melville from the north, and with four additional lines between the site and Tahiti to be obtained in ensuing operations, we anticipated collecting an underway data set that would address a number of these problems. Four additional days of ship time were funded by the National Science Foundation on the second Melville leg (the BPP/OBS recovery) to augment the time allotted for underway data collection and to allow the dredging of seamounts south and west of the Society Islands.

In addition to the regional surveys, a dense local survey of the target area by Melville was designed to help us select specific drilling targets and to establish constraints on the local tectonic framework, particularly the distribution of seamounts and abyssal hills. In the absence of concrete information about the direction of seafloor spreading from regional magnetic data, we decided to use the local strike of the abyssal hills to orient the refraction profiles for the anisotropy studies. We also configured the survey lines to investigate the nature of a large (200-km-long, 3000-m-high), arcuate ridge approximately $100 \mathrm{~km}$ east of the site, first found by our recontouring of the bathymetric data in preparation for Leg 91.

A particular question of regional significance is the lithologic nature of the "reverberant layer" detected in the Southwest Pacific Basin, especially to the north of the site, by Houtz and Ludwig (1979). Their isopach maps, derived from the interpretation of reflection profiler records, suggest the presence of as much as $100 \mathrm{~m}$ of well-stratified, reflective material beneath a 60 - to 100 -m-thick layer of acoustically transparent sediment in this region. Further south, near the Louisville Ridge, the reverberant layer is thicker and may comprise primarily volcaniclastic sediments derived from submarine eruptions or erosion of islands now submerged as guy- 
ots along the ridge. Such sediments were cored beneath a few tens of meters of pelagic clay and mud at DSDP Site 204 on Leg 21 (Burns, Andrews, et al., 1973), although there was little likelihood that similar sediments could form a regional blanket extending from the Louisville Ridge to the Leg 91 sites. Obtaining direct evidence on the nature of the reverberant layer was one objective of the drilling at Sites 595 and 596. Other objectives pertinent to the questions of regional tectonic history included collecting data on sediment age, paleolatitude, and the magnetic inclination of the sediments and underlying basalts.

The drilling also bears on two important aspects of the oceanic crustal composition: the chemistry and petrology of the lavas erupted at rapidly spreading ridges, and the nature and degree of alteration experienced by those lavas over the $100+$ m.y. of their posteruptive history. Previous drilling of the fast-spreading crust near the East Pacific Rise during Legs 34 and 54 failed to achieve any significant penetration of basalts. Rock freshness and hardness, the character of the lava flows, and the intense fracturing of the rocks repeatedly stopped drilling with only about $20-40 \mathrm{~m}$ of basement penetration (Shipboard Scientific Party, 1976; Natland and Rosendahl, 1980). It was entirely possible that a similar situation would arise at Site 595 and adversely impact the seismology experiment as well as future programs requiring basalt penetration. Assessing the role of posteruptive alteration and other physical properties of the basalts on the drilling operations was thus an objective. Also at issue was the relationship of the alteration to the low sediment accumulation rates characteristic of this area. Even with its low basement relief, apparently tens of million of years passed before the region became completely blanketed by sediments. This unusual situation implies that the circulation of seawater through the igneous crust could have continued much longer than on more rapidly sedimented ridge flanks. The rate and duration of the alteration processes may thus have depended more on the effectiveness of the circulation fluids in sealing fractures with alteration minerals than on the capping of the crust with impermeable sediments.

Finally, the drilling was intended to shed light on the peculiar sedimentary history of this ancient oceanic crust. We understood at the outset that the crust was probably formed at high southern latitudes near the center of what was then a Cretaceous or even Jurassic world ocean, the Atlantic then being only a narrow seaway. Sites 595 and 596 would thus be the first sampled with a sedimentary history reflecting great distances from both continental (including eolian) sources and areas of high or even average surface-water productivity; sediment cores from the holes would thus be of considerable paleoenvironmental interest. The low accumulation rates suggested that hydrothermally produced sediments rich in iron and manganese might be present in a particularly undiluted form above the basalts. The comparison of the composition of these sediments with those of younger pelagic clays in the same hole might also provide an important monitor of the dispersal of hydrothermal fluids from the spreading ridge.

\section{OPERATIONAL SUMMARY}

The technical complexities of the Ngendei Seismic Experiment required close operational coordination during Leg 91, particularly with regard to the phasing of the drilling activities and MSS deployment performed by Glomar Challenger with the OBS deployments and refraction shooting done by Melville. In this section, we summarize the operations aboard both vessels, including those during the Melville's BPP/OBS recovery leg subsequent to Leg 91. A chronology is provided in Table $1^{3}$; detailed descriptions of the various operations are deferred to the site chapters and technical papers.

Melville sailed from Honolulu, Hawaii, on January 9, 1983, and Glomar Challenger from Wellington, New Zealand, on January 16. Upon arrival at the primary target site, Melville began a site survey using $3.5-\mathrm{kHz}$ and $12-\mathrm{kHz}$ echosounders and a single-channel, digitally recorded water-gun system. Adequate sediment thickness was confirmed, and Melville guided Glomar Challenger to a specific drilling target at $23^{\circ} 49^{\prime} \mathrm{S}, 165^{\circ} 32^{\prime} \mathrm{W}$ upon the latter's arrival at the site on the afternoon of January 21.

Two pilot holes (595 and 595A) were drilled through a section with $70 \mathrm{~m}$ of pelagic clay and chert overlying easily penetrated basaltic basement (Fig. 2). The drilling of the main hole, 595B, commenced on 25 January and, after two reentries on 27 and 29 January, was completed 6 days later, reaching a sub-bottom depth of $124 \mathrm{~m}$, approximately $54 \mathrm{~m}$ into basement. Problems with the EM cable delayed the emplacement of the BIP until 5 February. On-deck recording of the BIP began early on the morning of 6 February.

Once installed in the borehole, calibration tests were run on all four seismometer sensors. The short-period vertical (SPZ), short-period vertical backup (SPZB), and short-period X (SPX) channels responded normally, but the short-period Y (SPY) channel deviated greatly from the calibration norm and exhibited a background noise level approximately $12 \mathrm{~dB}$ higher than the others. Although the $\mathrm{Y}$ instrument did record some signals from large shots and teleseisms, its performance degraded toward the end of the shipboard recording period. We suspect that internal failure of the sensor, perhaps caused by physical damage during BIP installation, was responsible for the poor data quality and improper calibration response of the SPY channel. Because of this failure, the horizontal components could not be oriented using calibration shots.

As a test of the teleseismic triggering algorithm and electronic modifications to the Scripps OBS design introduced for this experiment, Melville deployed two OBSs on 22 and 23 January at a site $30 \mathrm{~km}$ southwest of Hole 595B. The Melville then resumed regional survey activities, which were aimed at mapping the abyssal-hill orientation in the vicinity of the site in order to establish the local spreading direction. From the strike of a series

\footnotetext{
${ }^{3}$ The chronology in Table 1 is given in Universal Time (UT or Z), whereas the dates and times quoted in the text are local (L); at Sites 595 and 596, UT is obtained by adding $10 \mathrm{hr}$. to L (e.g., $1000 \mathrm{~L}=2000 \mathrm{Z})$.
} 
Table 1. Chronology of the Ngendei Seismic Experiment.

\begin{tabular}{|c|c|c|}
\hline $\begin{array}{l}\text { Date } \\
\text { (UT) }\end{array}$ & $\begin{array}{l}\text { Time } \\
\text { (UT) }\end{array}$ & Event \\
\hline $01 / 09$ & 2203 & Melville departs Honolulu, Hawaii \\
\hline $01 / 15$ & 2212 & Challenger departs Wellington, New Zealand \\
\hline $01 / 20$ & 1500 & Melville commences site survey \\
\hline \multirow[t]{5}{*}{$01 / 22$} & 0300 & Challenger drops beacon at Site 595 \\
\hline & 1630 & $\begin{array}{l}\text { Chief scientists of both ships meet aboard Challenger to } \\
\text { evaluate survey data }\end{array}$ \\
\hline & 1733 & First core recovered from Hole 595 \\
\hline & 2000 & Bit pulled clear of Hole 595 \\
\hline & 2220 & Challenger completes of fset $460 \mathrm{~m}$ east \\
\hline \multirow[t]{2}{*}{$01 / 23$} & 0023 & First core recovered from Hole $595 \mathrm{~A}$ \\
\hline & 0640 & $\begin{array}{l}\text { OBS Phred launched by Melville at Site PH1 for teleseis- } \\
\text { mic recording }\end{array}$ \\
\hline \multirow[t]{4}{*}{$01 / 24$} & 0527 & Last core recovered from Hole 595A \\
\hline & 0626 & OBS Janice launched at Site JA1 for teleseismic recording \\
\hline & 1857 & Drill bit arrives on deck from Hole 595A \\
\hline & 2300 & Melville resumes regional survey \\
\hline $01 / 25$ & 1524 & Hole 595B spudded \\
\hline $01 / 27$ & 2244 & First reentry to Hole 595B \\
\hline \multirow[t]{3}{*}{$01 / 29$} & 0102 & OBS Karen launched at Site KA1 for refraction recording \\
\hline & 1104 & OBS Juan launched at Site JUI for refraction recording \\
\hline & 1623 & Second reentry to Hole 595B \\
\hline \multirow[t]{2}{*}{$01 / 30$} & 0039 & OBS Suzy launched at Site SU1 for refraction recording \\
\hline & 1124 & OBS Lynn launched at Site LY1 for refraction recording \\
\hline \multirow[t]{3}{*}{$01 / 31$} & 0715 & OBS Janice recovered by Melville from Site JA1 \\
\hline & 1445 & Drill bit arrives on deck from Hole 595B \\
\hline & 1700 & $\begin{array}{l}\text { Challenger moves } 10 \text { nautical miles NE of site to dump } \\
\text { drilling line }\end{array}$ \\
\hline \multirow[t]{4}{*}{ 02/01 } & 0455 & OBS Janice launched at Site JA2 for teleseismic recording \\
\hline & 0915 & BIP-1 installed in carriage \\
\hline & 1428 & BIP-1 fails \\
\hline & 1809 & Melville begins shooting refraction line 1 (W to $\mathrm{E}$ ) \\
\hline \multirow[t]{5}{*}{$02 / 03$} & 0815 & OBS Janice recovered by Melville from Site JA2. \\
\hline & 1323 & End refraction line 1 \\
\hline & 1411 & Begin refraction line 2 (W to $\mathrm{E}$ and $10-\mathrm{km}$ circle) \\
\hline & 1923 & E action line 2 (W to $\mathrm{E}$ and $10-\mathrm{km}$ circle) \\
\hline & 1923 & End refraction line 2 \\
\hline \multirow[t]{2}{*}{$02 / 04$} & 1209 & Begin refraction line 3 (S to $N$ ) \\
\hline & 2330 & BIP-2 installed in carriage \\
\hline \multirow[t]{2}{*}{$02 / 05$} & 0749 & End refraction line 3 \\
\hline & 1433 & OBS Janice launched at Site JA3 for teleseismic recording \\
\hline \multirow[t]{5}{*}{$02 / 06$} & 0109 & Begin refraction line 4 (NE to $\mathrm{SW}$ ) \\
\hline & 0728 & Third reentry to Hole 595B \\
\hline & 1115 & BIP emplaced in bottom of hole \\
\hline & 1110 & On-deck recording of BIP begins \\
\hline & 1315 & Drill pipe recovery begun \\
\hline \multirow[t]{5}{*}{ 02/07 } & 0034 & End refraction line 4 \\
\hline & 0127 & ATNAV transponder X-1 launched $250 \mathrm{ft}$. SE of cone \\
\hline & 0130 & $\begin{array}{l}\text { Challenger moves } 1420 \mathrm{~m} \text { bearing } 310^{\circ} \text { from cone, paying } \\
\text { out EM cable }\end{array}$ \\
\hline & 0850 & OBS Phred recovered from Site PH1 \\
\hline & 1229 & Begin refraction line 5 (SE to NW) \\
\hline $02 / 08$ & 1200 & End refraction line 5 \\
\hline $02 / 09$ & 0152 & OBS Phred launched at Site PH2 for teleseismic recording \\
\hline & 0535 & OBS Juan recovered from Site JU1 \\
\hline & 0807 & OBS Karen recovered from Site KA1 \\
\hline & 1700 & $\begin{array}{l}\text { Melville chief scientists visit Challenger to evaluate seismic } \\
\text { data }\end{array}$ \\
\hline & 2345 & Melville deploys ASK beacon for IRR operations \\
\hline $02 / 10$ & 0556 & OBS Suzy recovered from Site SU1 \\
\hline & 0817 & OBS Lynn recovered from Site LY1 \\
\hline & 1136 & OBS Juan launched at Site JU2 for teleseismic recording \\
\hline & 2247 & OBS Suzy launched at Site SU2 for teleseismic recording \\
\hline & 2300 & $\begin{array}{l}\text { Challenger moves } 280 \mathrm{~m} \text { west to pay out remaining EM } \\
\text { cable }\end{array}$ \\
\hline $02 / 11$ & 0235 & BPP is moved from casing rack to port side of main deck \\
\hline & 0250 & $\begin{array}{l}\text { OBS Juan recovered from Site JU2 because of bad } \\
\text { diagnostics }\end{array}$ \\
\hline & 0818 & Begin refraction line 6 (SW fill-in of line 4) \\
\hline & 0945 & End refraction line 6 \\
\hline & 0957 & On-deck recording of BIP terminated \\
\hline & 1124 & OBS Juan launched at Site JU3 for teleseismic recording \\
\hline & 2142 & OBS Karen launched at Site KA2 for teleseismic recording \\
\hline & 2358 & BPP is lowered into water \\
\hline $02 / 12$ & 0315 & Paying out isolation link and riser leg begins \\
\hline & 0500 & Challenger begins moving on bearing $310^{\circ}$ \\
\hline & 0920 & BPP touches bottom \\
\hline & 1330 & A crown buoys attached to grapnel leg \\
\hline
\end{tabular}

Table 1 (continued).

\begin{tabular}{|c|c|c|}
\hline $\begin{array}{l}\text { Date } \\
\text { (UT) }\end{array}$ & $\begin{array}{l}\text { Time } \\
\text { (UT) }\end{array}$ & Event \\
\hline \multirow[t]{7}{*}{$02 / 12$} & 1357 & OBS Lynn launched at Site LY2 for teleseismic recording \\
\hline & 1457 & B crown buoys attached to grapnel leg \\
\hline & 1554 & Dual-release attached to anchor leg \\
\hline & 1858 & IRR anchor released from Challenger \\
\hline & 1948 & Melville observes submergence of B crown buoys \\
\hline & 2000 & Melville departs site \\
\hline & 2311 & Challenger completes survey over B crown buoy location \\
\hline \multirow[t]{5}{*}{$02 / 13$} & 0137 & ATNAV transponder X-3 deployed \\
\hline & 0253 & ATNAV transponder X-2 deployed \\
\hline & 0318 & Challenger underway from Site 595 \\
\hline & 0509 & 13.5-kHz beacon dropped at Site 596 \\
\hline & 1805 & BPP recording terminated by power failure \\
\hline \multirow[t]{2}{*}{$02 / 16$} & 1252 & Challenger departs Site 596 \\
\hline & 1900 & Melville arrives in Papeete, Tahiti \\
\hline $02 / 21$ & 0018 & Challenger arrived in Papeete, Tahiti \\
\hline $03 / 18$ & 0100 & Melville departs Papeete, Tahiti, on recovery leg \\
\hline \multirow[t]{3}{*}{$03 / 22$} & 0531 & OBS Suzy recovered from Site SU2 \\
\hline & 1100 & OBS Juan recovered from Site JU3 \\
\hline & 1520 & OBS Janice recovered from Site JA3 \\
\hline \multirow[t]{5}{*}{$03 / 23$} & 0600 & OBS Karen recovered from Site KA2 \\
\hline & 0905 & OBS Phred recovered from Site PH2 \\
\hline & 1040 & OBS Lynn recovered from Site LY2 \\
\hline & 1436 & Anchor leg of IRR mooring released \\
\hline & 1900 & B crown buoy recovered \\
\hline \multirow[t]{2}{*}{$03 / 24$} & 1934 & BPP on deck of the Melville \\
\hline & 2316 & Begin on-deck recording of BIP \\
\hline \multirow[t]{2}{*}{$03 / 25$} & 1533 & End on-deck recording of BIP \\
\hline & 2105 & Dummy BPP lowered into the water \\
\hline \multirow[t]{2}{*}{$03 / 26$} & 1040 & Dummy BPP touches bottom \\
\hline & 1800 & IRR anchor released from Melville \\
\hline $03 / 27$ & 0223 & MSS/OBS operations completed \\
\hline $04 / 05$ & 1800 & Melville arrives in Papeete, Tahiti \\
\hline
\end{tabular}

of ridges northwest of the site, this direction was estimated to be $\mathrm{N} 45^{\circ} \mathrm{W}$, and the refraction lines were oriented accordingly (Fig. 3). (As documented by Shearer et al., this volume, the refraction results give a much different estimate.)

From 28 to 30 January, four OBSs were programmed for the refraction experiment and deployed within about $600 \mathrm{~m}$ of the drilling site. The refraction shooting to the OBS array commenced at $0809 \mathrm{~L}$ on 1 February. The shooting pattern comprised four split profiles and one circular profile (Fig. 3). The navigation of the profiles and the locations of the shot points were unusually precise for marine work, because Melville was able to take radar ranges and bearings to Glomar Challenger out to distances of about $45 \mathrm{~km}$ and visual bearings on Glomar Challenger's derrick to about $30 \mathrm{~km}$. All four of the Scripps OBSs worked well during the refraction experiment, with two instruments recording each line.

Because of the delays associated with drilling Hole 595B and emplacing the BIP, the MSS recording of the refraction lines did not begin until $0120 \mathrm{~L}$ on 6 February, after Melville had shot lines 1-3, the NE (inbound) segment of Line 4 , and $10 \mathrm{~km}$ of the SW (outbound) segment of Line 4 . The latter gap was filled in by a short refraction profile (Line 6) shot on 10 February.

Despite the emplacement delays, approximately 350 refraction shots were recorded by the MSS on Lines 4, 5 , and 6; 335 of these (all except Line 6) were also recorded on at least two OBSs, providing a large data set for signal-comparison studies. Moreover, once MSS on-line recording had begun, the shot amplitudes at the BIP could 


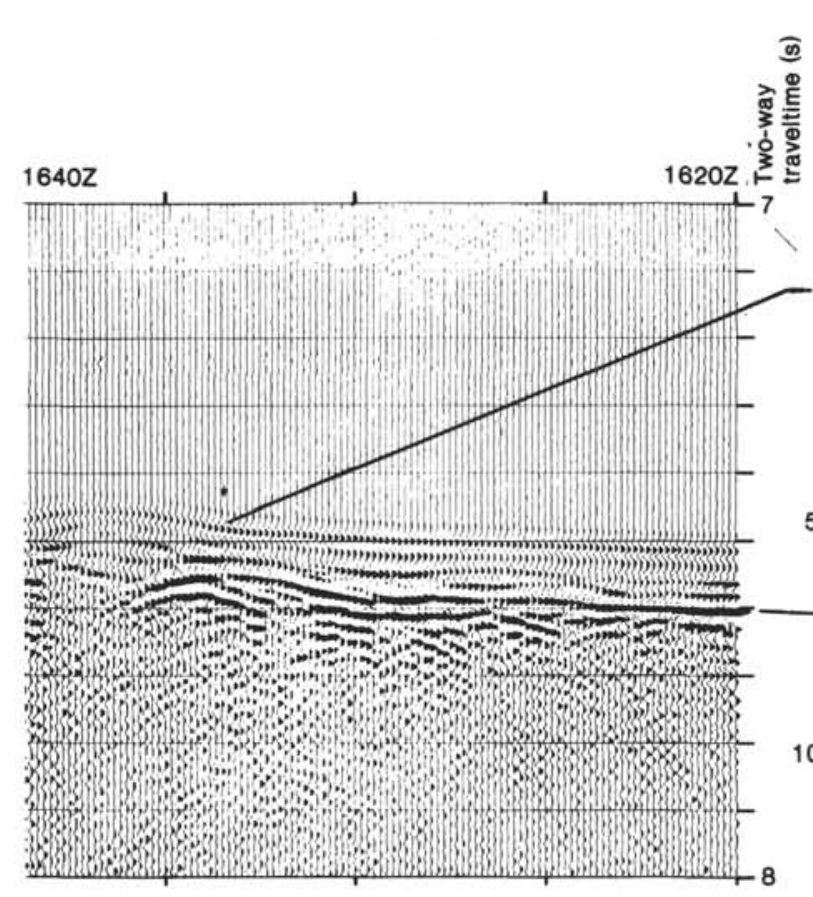

Single-channel water-gun reflection profile

$\overline{\underline{\varepsilon}}$

要完 音

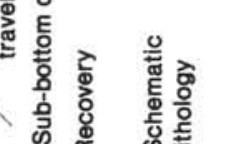
$(\mathrm{km} / \mathrm{s})$
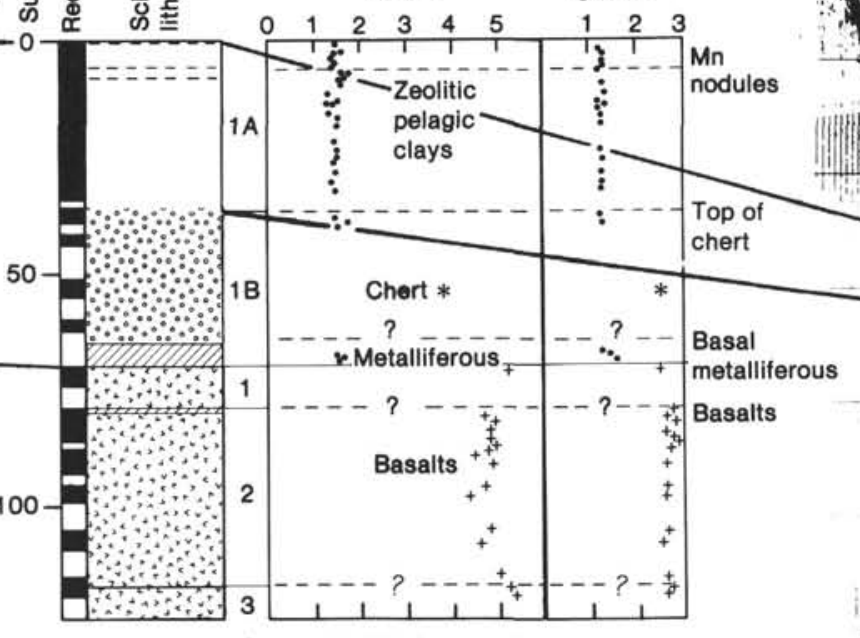

Composite lithology and physical properties vs. depth (Sites 595 and 596)

Melville 3.5-kHz

depth-sounding profile

Figure 2. Lithology of cores drilled during Leg 91 compared with a digital water-gun record on the left and a high-frequency, 3.5-kHz profiler record on the right. The top of chert-bearing sediments is clearly seen in the profiler record whereas the water-gun record more clearly shows the sediment/basement contact (see Kim et al., this volume). 


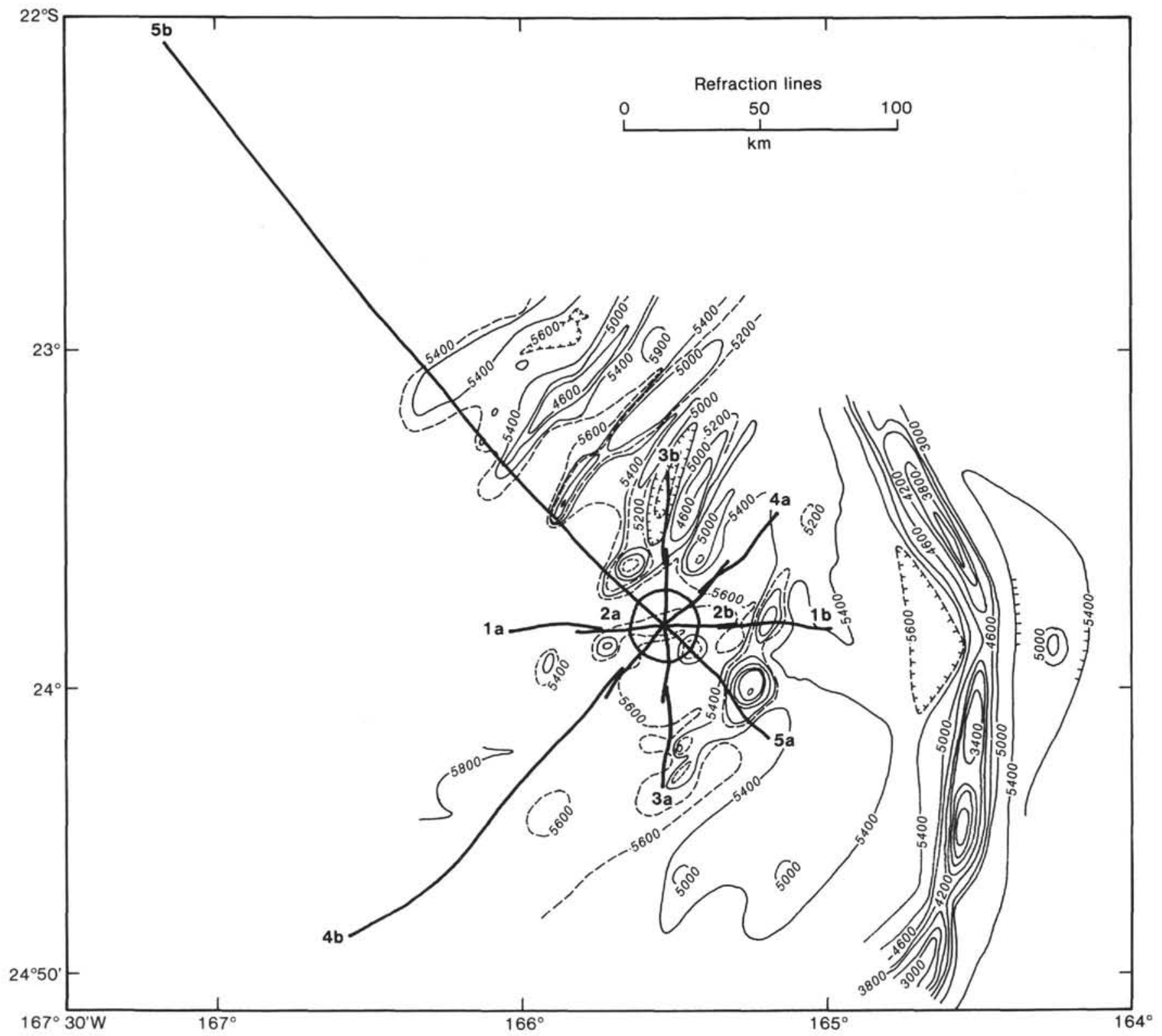

Figure 3. Detailed bathymetry of the area near Site 595 where the Ngendei refraction experiments were carried out. The orientation and sequence of short profiles 1, 2, and 3, and long profiles 4 and 5 are shown.

be monitored in real time aboard Glomar Challenger and radioed to Melville, allowing the shot sizes to be adjusted to maintain an adequate signal-to-noise ratio. In this way it was possible to extend Line 5 to $260 \mathrm{~km}$.

The recording of the BIP on the deck of Glomar Challenger continued for 5 days, during which an extensive program of simultaneous MSS/OBS noise comparisons was accomplished and a number of distant earthquakes were observed. The two OBSs deployed for the teleseismic test were recovered by Melville on 30 January and 6 February, and both recorded a number of events. The design modification proved to be successful, and it was learned from a shipboard analysis of the OBS data that a STA/LTA trigger ratio of 3:1 was optimal for this site. The four OBSs in the refraction array were recovered on 8-9 February, their filters were modified for teleseismic recording, and the controlling software was changed to incorporate the appropriate trigger ratio. The entire sixelement OBS array was then relaunched for the longterm teleseismic recording experiment, the last deployment being completed on 12 February. Four OBS were placed in a tight array ( $\sim 2 \mathrm{~km}$ aperture) near the BIP, and two were deployed at locations about $30 \mathrm{~km}$ east and south of the BIP.

The on-deck recording of the BIP was terminated just before midnight on 10 February, and the BIP was lowered over the side of Glomar Challenger the next day. Because of a failure in the BIP data transceiver unit, which resulted in the loss of the midperiod vertical data channel and the status/control communications between the package and the BPP, the backup short-period vertical seismic channel was selected for acquisition by the 
BPP during its seafloor deployment. The IRR anchor was released from Glomar Challenger at $0858 \mathrm{~L}$ on 12 February, and Melville observed the submergence of the B-crown buoys about $50 \mathrm{~min}$. later. Melville then departed the site for Tahiti, shooting a few shots on an exit profile to orient the OBS horizontals. Melville arrived in Papeete on 16 February.

After surveying the MSS deployment and releasing two additional navigation transponders for the planned recovery operations, Glomar Challenger departed Site 595 at $1818 \mathrm{~L}, 12$ February. She steamed approximately $8 \mathrm{n}$. mi. west-southwest to a new site, 596, preselected on the basis of earlier profiling by the Melville. The $13.5-\mathrm{kHz}$ beacon was dropped at Site 596 at $1909 \mathrm{~L}$. After initial failures, which resulted in the jamming of the HPC assembly and required a round trip of the pipe to dislodge, a series of cores were taken in Hole 596, penetrating about $71 \mathrm{~m}$ of sediment and $5 \mathrm{~m}$ of basement. Recovery of the basal sedimentary sequence was poor, so a new hole (596A) was spudded and drilled to $66 \mathrm{~m}$ below seafloor, where a single 4-m segment of the basal section was cored. Scheduling permitted a final hole, 596B, and a 9-m core was taken at about $25 \mathrm{~m}$ below seafloor. Glomar Challenger departed Site 596 at 0252 L on 16 February, arriving in Papeete on 20 February.

Melville departed Papeete for the recovery leg of the Ngendei Experiment on 17 March, arriving back on the site on 21 March. All six OBSs were recovered without incident by early morning $23 \mathrm{March}$. The total OBS deployment times varied from 39 to 47 days, with all instruments recording teleseismic earthquake data and noise samples.

BPP recovery operations began on 23 March and were completed the next day. The BPP was opened up on deck, and it was found that only about $40 \mathrm{hr}$. of data had been logged on magnetic tape before a power failure caused by a leak in one of the battery spheres terminated the recording. However, seven additional hours of BIP data were obtained on the morning of $25 \mathrm{March}$, during the period the EM cable was connected to the on-deck recording gear. After verifying that the BIP was operational, the EM cable was attached to a dummy BPP, and the IRR system was redeployed. Melville left the site on the afternoon of 26 March. After 8 days of surveying and dredging seamounts southwest of the Society Islands and running a number of gravity profiles, Melville arrived back in Papeete on 5 April, 1983.

\section{VOLUME ORGANIZATION AND AUTHORSHIP}

Volume 91 follows the conventional format for Initial Reports in having this introductory chapter followed by site reports and then individual contributions divided topically into several parts. However, because Leg 91 had an unusual engineering emphasis, several of the contributions are concerned strictly with describing seismological instruments and their operation. These were submitted to technical review by qualified experts, but not scientific review inasmuch as they provide no scientific data and offer no interpretations of data except in an engineering sense. All other contributions involving data presentation and interpretation were reviewed for scientific content using standard DSDP procedures.

The site reports concern the activities of Glomar Challenger personnel during the Ngendei Seismic Experiment. Although the closely integrated operations of Melville are outlined in the site reports, the details of those operations are only given in particular scientific and engineering contributions to this volume, and in Tables 1 and 2 of this chapter.

The site reports were written by members of the Scientific Party of Leg 91 with general responsibility for authorship summarized as follows:

Drilling Operations:

$$
\text { G. N. Foss }
$$

Sediment Descriptions:

W. Mills and J. Natland

Basalt Descriptions:

E. Rosencrantz and J. Natland

Physical Properties:

W. Smith and R. Whitmarsh

The Seismic Experiments:

R. Whitmarsh, R. Adair, R. Prevot, and D. Smith

Site Selection:

H. W. Menard

Correlation of Physical Properties and Underway

Geophysics:

H. W. Menard and D. Smith

This chapter provides an introduction to the site reports and an overall summary of cruise operations. Since the principal scientific results of the Ngendei Experiment required months of shore-based data evaluation, the site reports do not provide the Summary and Conclusions usually offered in such site chapters.

\section{EXPLANATORY NOTES}

\section{General Information}

The purpose of these notes is twofold. First, they are intended to aid interested investigators in understanding (1) the terminology, labeling, and numbering conventions used by the Deep Sea Drilling Project and (2) the sediment classification and biostratigraphic framework used on Legs 88 and 91 . Second, they are intended to explain the preliminary lithologic and paleontologic data on the core forms.

\section{Numbering of Sites, Holes, Cores, and Samples}

DSDP drill sites are numbered consecutively from the first site drilled by Glomar Challenger in 1968. Site numbers differ from hole numbers in that a site number refers to a locale where one or more holes were drilled while the ship was positioned over one acoustic beacon. These holes could be located within a radius as great as $900 \mathrm{~m}$ from the beacon. Several holes may be drilled at a single site by pulling the drill pipe above the seafloor (out of the hole), moving the ship $100 \mathrm{~m}$ or more from the previous hole, and then beginning to drill another hole.

The first (or only) hole drilled at a site takes the site number. A letter suffix is applied to each additional hole 
Table 2. Seismometer deployments during the Ngendei Seismic Experiment.

\begin{tabular}{|c|c|c|c|c|c|c|c|c|c|}
\hline \multirow{2}{*}{$\begin{array}{l}\text { Instrument } \\
\text { name }\end{array}$} & \multirow{2}{*}{$\begin{array}{l}\text { Deployment } \\
\text { number }\end{array}$} & \multicolumn{2}{|c|}{ Sensor location } & \multirow{2}{*}{$\begin{array}{c}\text { Sensor } \\
\text { depth } \\
\text { (m) }\end{array}$} & \multicolumn{2}{|c|}{ Recording interval (UT) } & \multirow{2}{*}{$\begin{array}{l}\text { Recording } \\
\text { mode }^{\mathrm{a}}\end{array}$} & \multirow{2}{*}{$\begin{array}{l}\text { Refraction } \\
\text { lines }\end{array}$} & \multirow[b]{2}{*}{ Comments } \\
\hline & & Lat. $\left({ }^{\circ} \mathrm{S}\right)$ & Long. $\left({ }^{\circ} \mathrm{W}\right)$ & & First record & Last record & & & \\
\hline \multirow[t]{3}{*}{ BIP-2 } & MS1 & $23^{\circ} 49.34^{\prime}$ & $165^{\circ} 31.61^{\prime}$ & 5739 & & & Challenger deck & $4 b, 5,6$ & $\begin{array}{l}\text { Gould SZ inoperable } \\
\text { Y-sensor and hole lock inoperable }\end{array}$ \\
\hline & MS2 & $23^{\circ} 49.34^{\prime}$ & $165^{\circ} 31.61^{\prime}$ & 5739 & $02 / 1121: 42$ & $02 / 1318: 05$ & BPP on seafloor & & $\begin{array}{l}\text { BPP power failure after } 40 \mathrm{hr} \text {. } \\
\text { Y-sensor and hole lock inoperable }\end{array}$ \\
\hline & MS3 & $23^{\circ} 49.34^{\prime}$ & $165^{\circ} 31.61^{\prime}$ & 5739 & & & Melville deck & & $\begin{array}{l}\text { Gould SZ and NZ inoperable } \\
\text { Y-sensor and hole lock inoperable }\end{array}$ \\
\hline \multirow[t]{2}{*}{ OBS Phred } & PH1 & $23^{\circ} 56.51^{\prime}$ & $165^{\circ} 45.68^{\prime}$ & 5676 & 01/23 13:11 & 02/06 17:19 & TT & & \\
\hline & PH2 & $23^{\circ} 49.44^{\prime}$ & $165^{\circ} 32.39^{\prime}$ & & $02 / 1105: 43$ & $03 / 23 \quad 07: 37$ & TT & & \\
\hline \multirow[t]{3}{*}{ OBS Janice } & JA1 & $23^{\circ} 56.04^{\prime}$ & $165^{\circ} 47.19^{\prime}$ & 5704 & $01 / 2414: 58$ & $01 / 3102: 58$ & $\mathrm{TT}$ & & \\
\hline & JA2 & $23^{\circ} 56.17^{\prime}$ & $165^{\circ} 46.00^{\prime}$ & 5717 & No data & & TT & & A/D board in incorrect slot \\
\hline & JA3 & $23^{\circ} 49.09^{\prime}$ & $165^{\circ} 31.55^{\prime}$ & 5605 & 02/08 23:58 & 03/21 23:58 & TT & & \\
\hline \multirow[t]{2}{*}{ OBS Karen } & KA1 & $23^{\circ} 49.04^{\prime}$ & $165^{\circ} 31.65^{\prime}$ & 5612 & 02/01 11:10 & 02/09 06:00 & RS & 3,4 & \\
\hline & KA2 & $23^{\circ} 48.56^{\prime}$ & $165^{\circ} 32.50^{\prime}$ & 5593 & $02 / 1210: 14$ & $03 / 22 \quad 22: 59$ & TT & & \\
\hline \multirow[t]{3}{*}{ OBS Juan } & JU1 & $23^{\circ} 49.21^{\prime}$ & $165^{\circ} 31.95^{\prime}$ & 5618 & 02/01 11:20 & 02/09 00:00 & RS & 3,4 & $\begin{array}{l}\text { Hydrophone recorded poorly } \\
\text { Channel } 3 \text { not recorded }\end{array}$ \\
\hline & JU2 & & & & No data & & TT & & \\
\hline & JU3 & $24^{\circ} 02.72^{\prime}$ & $165^{\circ} 31.81^{\prime}$ & 5579 & $02 / 11 \quad 18: 17$ & $02 / 25$ 05:18 & $\mathrm{TT}$ & & \\
\hline \multirow[t]{2}{*}{ OBS Suzy } & SU1 & $23^{\circ} 49.04^{\prime}$ & $165^{\circ} 31.65^{\prime}$ & 5612 & 02/01 $17: 20$ & 02/09 23:55 & RS & $1,2,5$ & \\
\hline & SU2 & $23^{\circ} 51.60^{\prime}$ & $165^{\circ} 17.80^{\prime}$ & 5654 & $01 / 11 \quad 05: 42$ & $03 / 2200: 24$ & TT & & \\
\hline \multirow[t]{2}{*}{ OBS Lynn } & LY1 & $23^{\circ} 49.24^{\prime}$ & $165^{\circ} 31.87^{\prime}$ & 5603 & 02/01 17:10 & 02/10 05:55 & RS & $1,2,5$ & Channel 2 not recorded \\
\hline & LY2 & $23^{\circ} 48.74^{\prime}$ & $165^{\circ} 33.07^{\prime}$ & 5503 & $02 / 12 \quad 20: 20$ & 03/23 07:08 & TT & & \\
\hline
\end{tabular}

${ }^{\mathrm{a}} \mathrm{TT}=$ teleseismic trigger mode; $\mathrm{RS}=$ refraction schedule mode.

at the same site. For example, the first hole takes only the site number, the second takes the site number with suffix $A$, the third takes the site number with suffix B, and so forth. It is important, for sample-labeling purposes, to identify the hole drilled at the site, since sediments or rocks recovered from different holes usually do not come from equivalent positions in the stratigraphic column.

The cored interval is measured in meters below the seafloor. The depth interval for an individual core is the depth below seafloor at which the coring operation began to the depth at which the coring operation ended. Most core intervals are $9.5 \mathrm{~m}$ long, the nominal length of a core barrel; however, the coring interval may be shorter or slightly longer. Cored intervals are not necessarily adjacent to each other, but may be separated by drilled intervals. In soft sediment, the drill string can be washed ahead with the core barrel in place, but not recovering sediment, by pumping water down the pipe at high pressure to wash the sediment out of the way of the bit and up the space between the drill pipe and the wall of the hole. However, some material does occasionally get caught in the core barrel while the drill string is being washed ahead; thus, it is possible to have a cored interval greater than $9.5 \mathrm{~m}$.

Full recovery for a single core is normally $9.28 \mathrm{~m}$ of sediment or rock, which is in a plastic liner (6.6 cm ID), plus a sample about $0.1 \mathrm{~m}$ long (without a plastic liner) in the core catcher. The core catcher is a device at the bottom of the core barrel that prevents the cored sample from sliding out when the barrel is being retrieved from the hole. The core is then cut into 1.5 -m-long sections and numbered serially from the top of the core (Fig. 4). When a core is fully recovered, the sections are numbered from 1 to 7 , with the last section shorter than $1.5 \mathrm{~m}$. The core-catcher sample is placed below the last section when the core is described and labeled core catcher (CC); it is treated as a separate section.
When recovery is partial, the original stratigraphic position of the material in the cored interval is unknown. If the recovered material is contiguous we assign the top of this material to the top of the cored interval and number sections serially from the top, beginning with Section 1 (Fig. 4). (This technique differs from the labeling system used for Legs 1 through 45 , in which one section was numbered 0 and none was numbered 7.) There are as many sections as needed to accommodate the length of the recovered material. For example, $4 \mathrm{~m}$ of material are divided into three sections, two upper sections each $1.5 \mathrm{~m}$ long and a final lower section only $1.0 \mathrm{~m}$ in length. If the material recovered is not contiguous, as determined by the shipboard scientists, the sections are divided and numbered serially as with contiguous material, and the gaps are labeled as voids for sediments (Fig. 4) or marked by spacers for igneous rocks (see Igneous Rocks section).

Samples are designated by the interval, in centimeters, from the top of the section to the top and bottom of the sample. A full identification number for a sample consists of leg, site, hole, core, and interval (in centimeters from the top of the section). For example, a sample identification number of 91-595A-3-1, 12-14 cm is interpreted as the sample $12-14 \mathrm{~cm}$ from the top of Section 1 of Core 3 from the second hole drilled at Site 595 during Leg 91. A sample from the core catcher of this core is designated as $91-595 \mathrm{~A}, \mathrm{CC}$.

\section{Handling of Cores}

A core is normally cut into $1.5-\mathrm{m}$ sections, sealed, and labeled. It is then taken to the core laboratory for processing. During these legs, thermal conductivity measurements, and continuous wet-bulk density determinations using the gamma-ray attenuation porosity evaluation (GRAPE) were made before the sections were split.

The cores were than split longitudinally into working and archive halves. Samples were taken from the working half for analysis. Samples were analyzed for grain- 


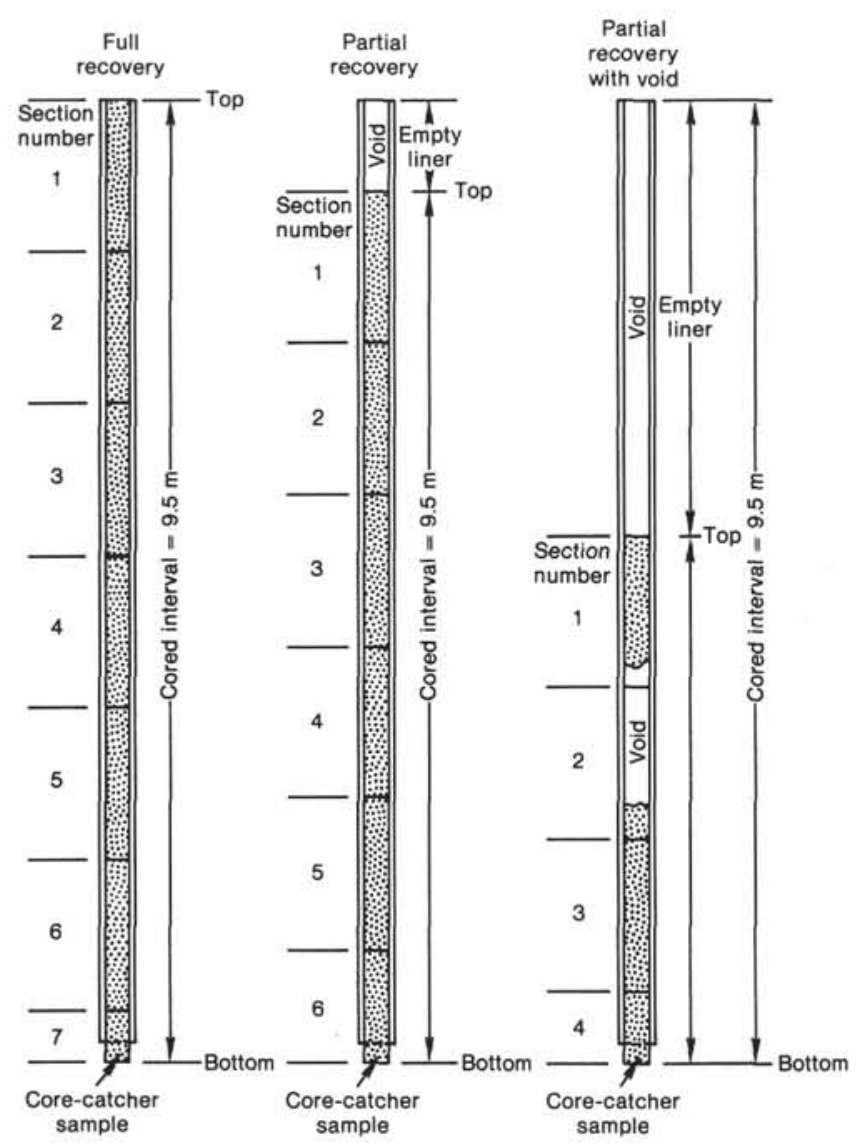

Figure 4. Diagram showing procedures in cutting and labeling of core sections.

size distribution, mineralogy (by X-ray diffraction), sonic velocity (by the Hamilton frame method), wet-bulk density (by a static GRAPE technique), water content (by gravimetric analysis), calcium carbonate content (by the carbonate bomb technique), geochemistry, and paleontology, among other things.

Smear slides (thin sections) were prepared for lithified sedimentary and igneous rocks from each major lithology and most minor lithologies and examined microscopically. The archive half was then described and photographed. Physical disturbance by the drill bit and the color, texture, structure, and composition of the various lithologies were noted on standard core description forms. All prime data were microfilmed, and some were digitized for computer retrieval.

After the cores were sampled and described, they were kept in cold storage aboard Glomar Challenger until they could be transferred to the DSDP repository. Core sections of sediments intended for the study of organic geochemistry were frozen immediately on board ship and kept frozen. All fresh and frozen cores described here are presently stored at the DSDP West Coast Repository (Scripps Institution of Oceanography).

\section{Hydraulic Piston Corer}

On Leg 91 the variable-length hydraulic piston corer (HPC) was used successfully to recover undisturbed sediments at Site 596. The high rate of recovery was attrib- uted to the low shear strength of the sediments and calm seas. HPC-drilled holes are not given any special designation.

The principles of operation of the hydraulic piston corer are outlined in Figure 5. The hydraulic piston corer is located within the lowermost part of the drill string, and it is flush with the base of the drill bit before it is fired. Once fired, the cores ideally penetrate $9.0 \mathrm{~m}$ into the underlying sediment. The full extension of the HPC to this length is reflected on the rig floor by complete pressure bleed-off following the shot. After penetrating the sediment the HPC is pulled up to a position within the lowermost part of the drill string. The whole drill string is then raised to a point where a drill string tool joint appears at the level of the rig floor. The raised interval ranges from 0 to $9.5 \mathrm{~m}$ (the length of one joint of drill pipe). Thus, the total depth of the open hole beneath the drill bit can be as high as $9.5+9.0 \mathrm{~m}$ or $18.5 \mathrm{~m}$. The drill string is then separated at the tool joint, and the inner core barrel with sediment within is pulled to the rig floor on the sandline.

After the core is removed, the inner core barrel of the HPC is reloaded and returned to the base of the drill string. The HPC drill bit then washed down through the sediment interval just previously cored, but only for a distance about $1 \mathrm{~m}$ less than the distance penetrated by the previous core. The last meter of lowering is done without washing. The base of the drill string is now at the desired level for the next HPC shot.

The presence of an open hole below the drill string while the HPC inner core barrel is being retrieved and reloaded and the fact that the drill string washes down and is pushed the last meter begins to explain why the upper part of many hydraulic piston cores are contaminated with material previously cored and disturbed. The raising of the entire drill string as much as $9.5 \mathrm{~m}$ also explains why a mudline core may be taken twice.

\section{Sediments and Sedimentary Rocks}

\section{Core Description Forms}

\section{Disturbance}

Recovered rocks, particularly the soft sediments, may be extremely disturbed as a result of rotary coring, which uses a large $(25-\mathrm{cm}$-diameter) bit with a small $(6.0-\mathrm{cm}$ diameter) opening for the core sample. The following disturbance categories are used for soft and firm sediment:

Slightly deformed: bedding contacts are slightly bent.

Moderately deformed: bedding contacts have undergone extreme bowing. Firm sediment is fractured.

Very deformed: bedding is completely disturbed or homogenized by drilling and sometimes shows symmetrical diapirlike structure. Firm zones may have relic drill biscuits in a breccia or homogeneous matrix.

Soupy: water-saturated intervals that have lost all aspects of original bedding.

These categories are indicated on the core description form in the column headed "Drilling Disturbance" (Fig. 6). 
1

$\mathrm{HPC}$ is seated and seawater pumped at $350 \mathrm{gpm}$ to actuate

(Length is 36 feet collapsed and 50 feet extended)

Stationary sealing top sub

Orientation marker 4.4-m stroke

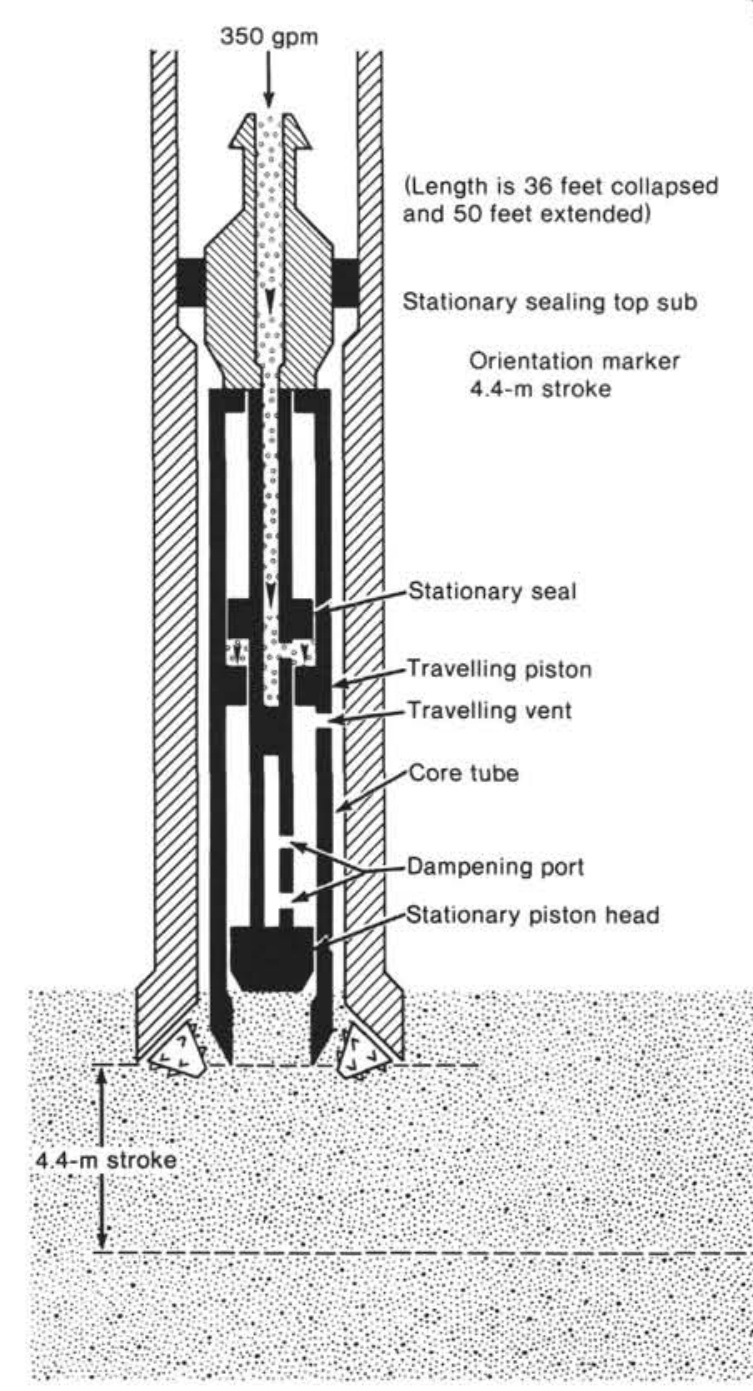

Figure 5. Operational sequence of the hydraulic piston corer.

\section{Sedimentary Structures}

In the softer sedimentary cores, and even in some harder ones, it may be extremely difficult to distinguish between natural structures and structures created by the coring process. Thus, the description of sedimentary structures is optional. Locations and types of these structures appear as graphic symbols in the column headed "Sedimentary Structures" on the standard core description form (Fig. 6) and the expanded hydraulic piston core description form (Fig. 7). Figure 8 gives the key to these symbols. The key for the graphic lithology column is given in Figure 9.

Bioturbation, where detected, is noted in the graphic lithology column. A summary of the biogenic sedimentary structures (ichnofossils) most common in DSDP cores is given in Figure 10.

\section{2}

Locking pins shear at 1700 psi; pressure on travelling piston drives core tube; fluid above stationary piston is vented: (1) approximately

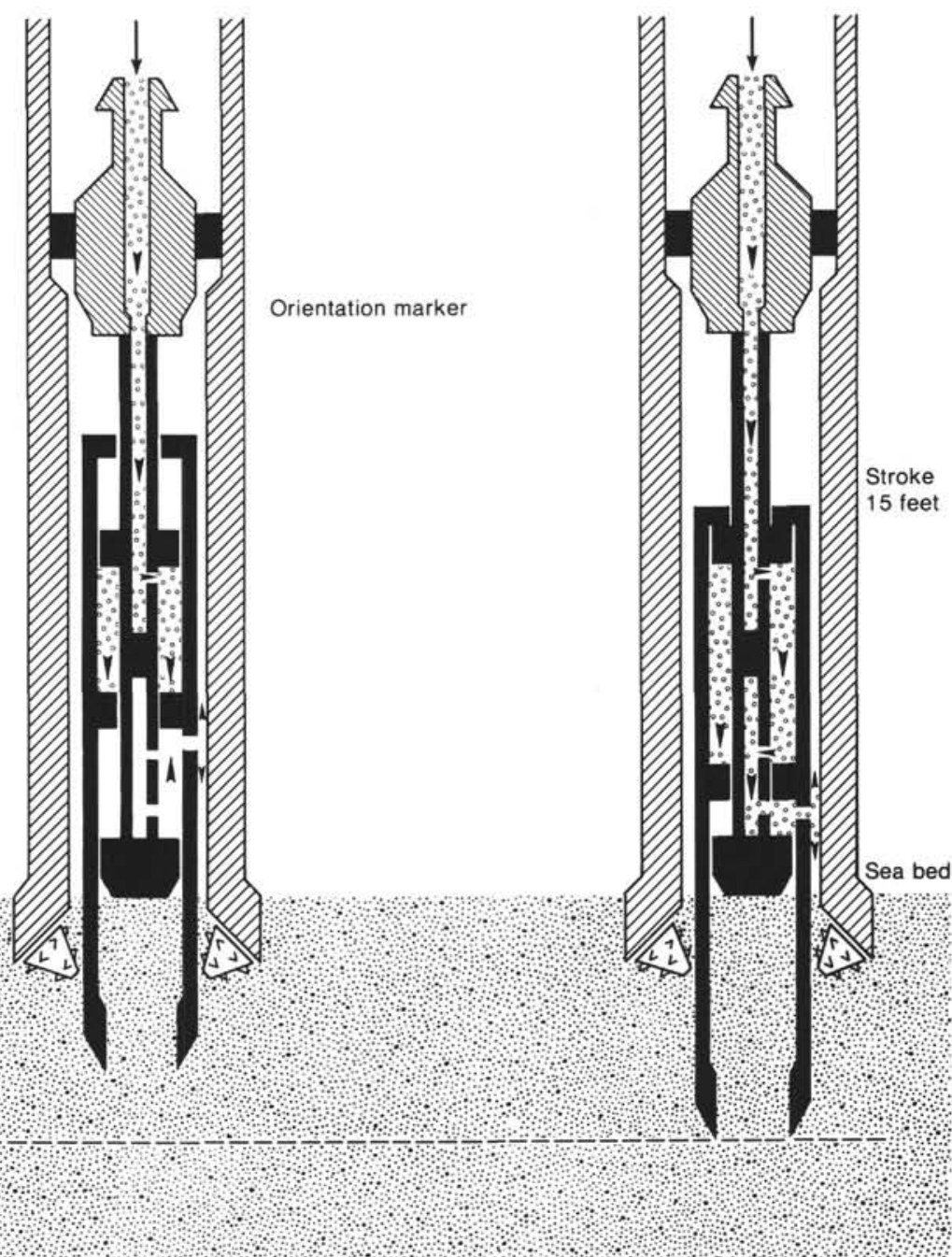

At the end of the stroke that vent the pressure fluid and decelerate the core tube dampening ports are uncovered 
T. H. JORDAN, H. W. MENARD, J. H. NATLAND, J. ORCUTT

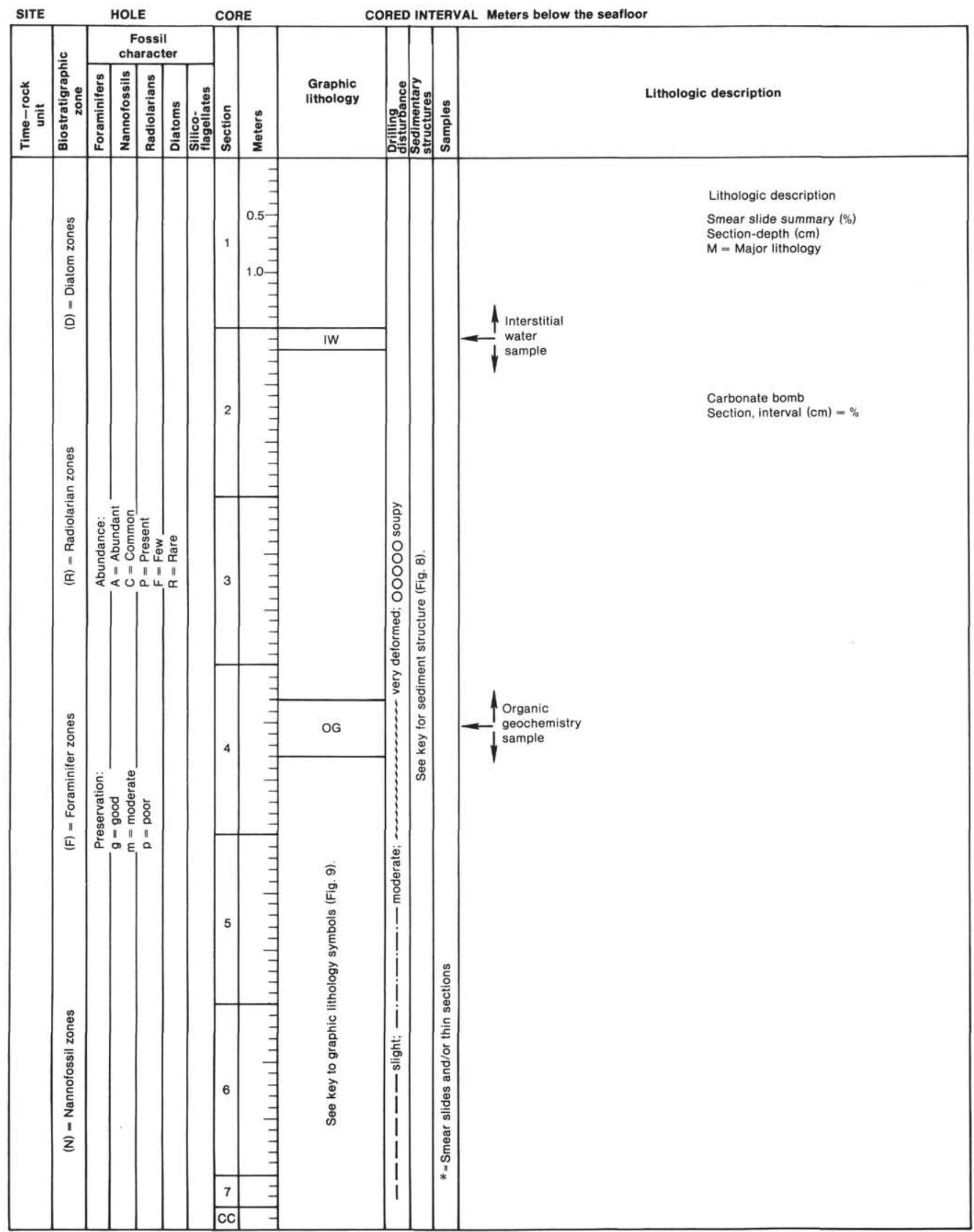

Figure 6. Sedimentary core description sheet with the sediment deformation symbols, sample codes, and other general information. 


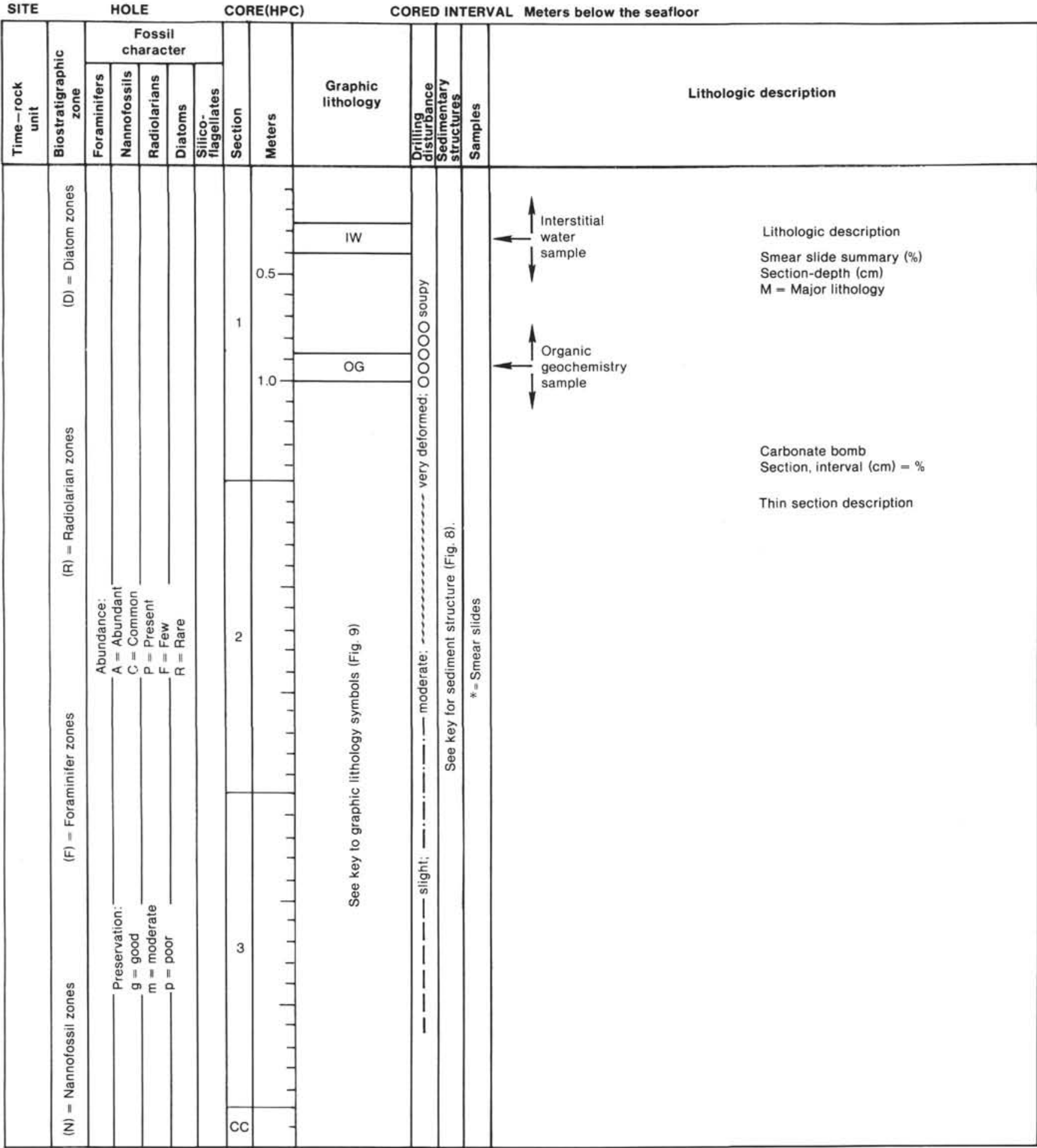

Figure 7. Sample core form, hydraulic piston corer.

portion of the graphic column its pattern occupies. For example, the left $20 \%$ of the column may have a diatom ooze pattern and the right $80 \%$ of the column may have a silty-clay pattern indicating sediment composed of $20 \%$ diatoms and $80 \%$ mud.

Because of the difference in the length-to-width ratio between the actual sediment core and the graphic lithol- ogy column, it is not possible to reproduce structures as they appeared in the core; they become highly flattened and distorted. The same is true for rock fragments or pebbles in the cores. As a result, the locations of pebbles are shown by a solid square, and the depth of small patches of ash or other lithologic changes are indicated by a triangular inset of the appropriate lithologic symbol on 


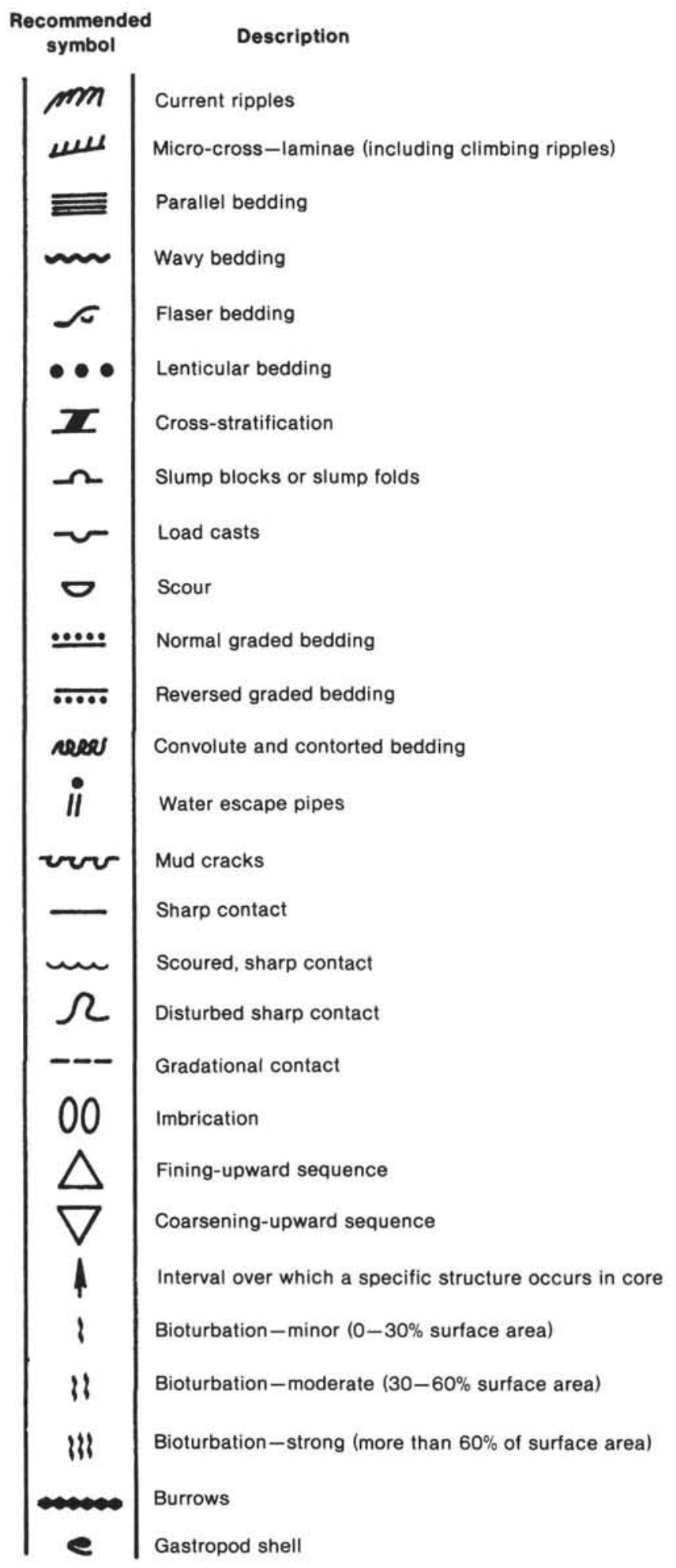

Figure 8. Symbols used to identify sedimentary structures on core description forms.

the right side of the lithologic column (Fig. 9). This convention is used only for lithologies that do not extend across the entire core.

The content, format, and terminology used in the written description of the core on the core description forms (Figs. 6 and 7) are not controlled beyond the name as- signed to the lithology, which is derived from the lithologic classification (described below). Colors and such additional information as structures and texture appear in the text portion of the core description.

Smear slide (or thin section) compositions, carbonate content $\left(\% \mathrm{CaCO}_{3}\right)$, and organic carbon content determined on board ship are listed below the core description on these forms. Two numbers separated by a hyphen refer to the section and centimeter interval, respectively, of the sample. The locations of these samples in the core and a key to the codes used to identify these samples are given in the column headed "Samples" (Figs. 6 and 7). The locations and intervals of organic geochemistry (OG) and interstitial water (IW) samples are given in the lithology column.

\section{Lithologic Classification of Sediments}

The classification system used here was devised by the JOIDES Panel on Sedimentary Petrology and Physical Properties (SPPP) and adopted for use by the JOIDES Planning Committee in March 1974. The classification is descriptive rather than genetic, and divisions between different types of sediment are somewhat arbitrary. A brief outline of the conventions and descriptive data used to construct this classification follows. Since the range of sediment types recovered is limited, we do not present the entire classification scheme but only what is pertinent to our cores. This excludes terrigenous, most volcanogenic, and special (e.g., hydrothermal) sediment types. The most recent publication of the complete sediment classification system was published in Ross, Neprochnov, et al. (1978).

\section{Conventions and Descriptive Datü \\ Composition and Texture}

In this classification system, composition and texture are the only criteria used to define the type of sediment or sedimentary rock. Composition is most important for describing sediments deposited in the open ocean, and texture becomes significant for hemipelagic and nearshore sediments. These data come principally from visual estimates of smear slides used a petrographic microscope. The estimates are based on the areal abundance and size of the components on the slide and may differ somewhat from accurate analyses of grain size, carbonate content, and mineralogy (see Special Studies). Because of past experience, the quantitative estimates of distinctive minor components are accurate within $2 \%$, but for major constituents the accuracy is poorer $( \pm 10 \%)$. All smear slide estimates were done on board. Percentages of carbonate ranged from very low to nil; no quantitative measurements using either the carbonate bomb or Leco 70-s microanalyzer were made.

The textures of the sediments and the percentages of sand, silt, and clay estimated from the smear slides include all constituents. Thus, a diatomaceous ooze will have a greater percentage of silt-sized particles than a nannofossil ooze because of the different size of the tests of the two planktonic groups. This convention causes some confusion when terrigenous sediments that contain a significant number of microfossils are named. For 
Pelagic

Nonbiogenic

Pelagic clay

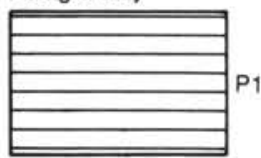

Siliceous biogenic

Pelagic siliceous biogenic - soft

Diatom ooze

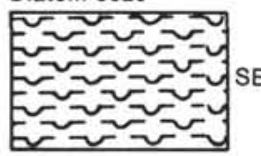

Pelagic siliceous biogen

Diatomite

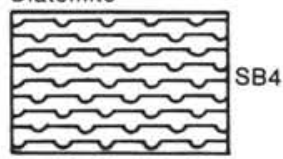

SB 4

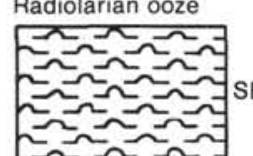

Vertical bar percen

\%) designation for

graphic log

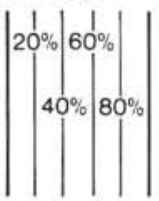

Diatom-radiolarian

or siliceous ooze

FE= =

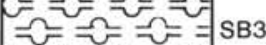

$p=0=0==0$

$\Omega=\Omega \Omega=$

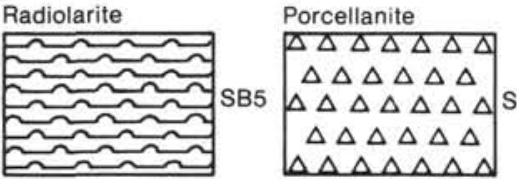

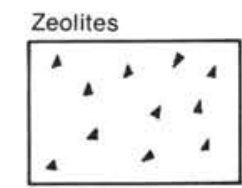

Transitional siliceous terrigenous sediments
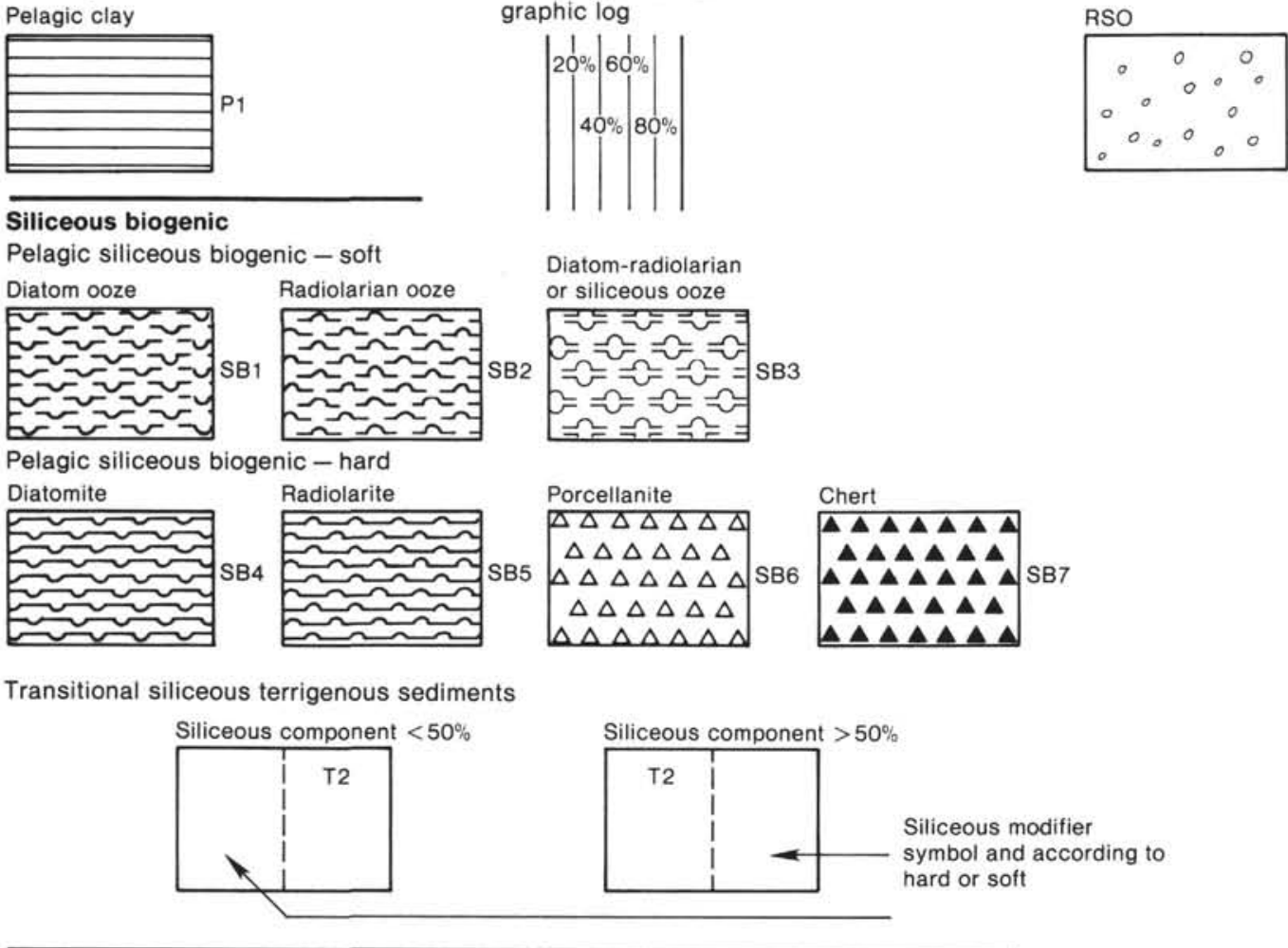

\section{Calcareous biogenic}

Pelagic biogenic calcareous - soft

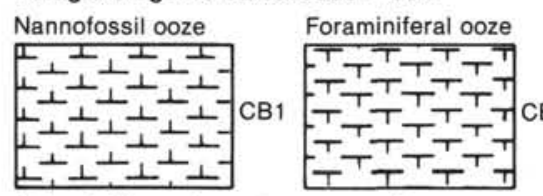

Pelagic biogenic calcareous - firm

\begin{tabular}{|c|c|c|c|}
\hline \\
\hline
\end{tabular}

Foraminiferal chalk

Pelagic biogenic calcareous - hard

Limestone
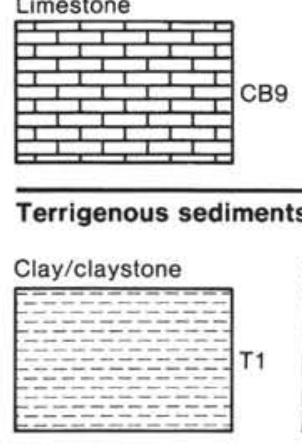

Silty sand/

sandy silt
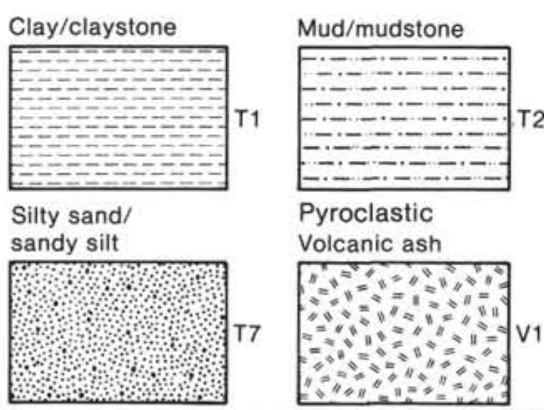

Nanno-foram or

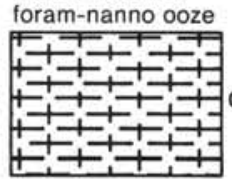

Calcareous ooze

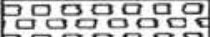

CB3

맘ㅁㅁㅁㅁㅁ을

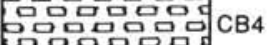

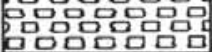

Nanno-foram or

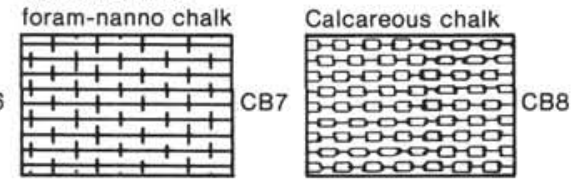

Figure 9. Symbols used to identify lithology on sediment core description forms (Figs. 6 and 7). Note special Leg 91 symbols for zeolites and RSOs. 


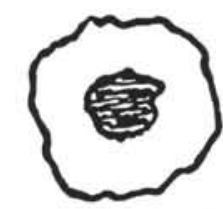

Hollow Cylindrichnus

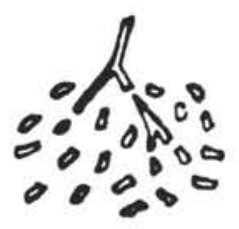

Chondrites

\section{DDDDDDDDDDDDDDDD}

Simple Zoophycos

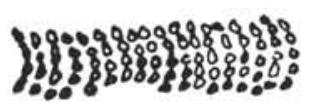

Pelleted Zoophycos

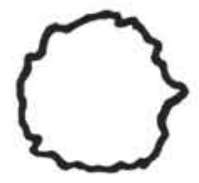

Solid Cylindrichnus

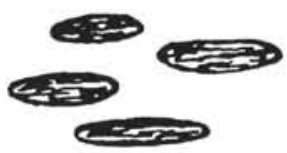

Planolites

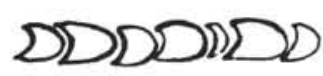

Fat Zoophycos

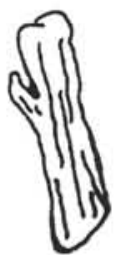

Figure 10. Most common trace fossils in Deep Sea Drilling Project cores.

example, a diatomaceous silty clay may have fewer siltsized terrigenous particles (e.g., quartz and feldspar) than a nannofossil silty clay simply because many diatoms are silt sized and are included as such in the textural estimate. However, we have chosen fairly broad compositional class boundaries for mixed terrigenous and biogenic sediments (see below) in order to minimize this effect. For this reason we preferred to replace clayey-silt or silty-clay by mud in combination with a biogenic modifier.

We used as many modifiers as necessary to describe the type of sediment encountered. In all cases the dominant component appears last in the name; minor components precede, with the least common constituent listed first. Constituents that occur in amounts less than $10 \%$ are not included in the name. This convention also holds for zeolites, $\mathrm{Fe}$ - and $\mathrm{Mn}$-micronodules, and other indicators of very slow rates of sedimentation or nondeposition, such as fish teeth. Often these minerals are conspicuous even though greatly diluted, and they are sometimes included in the name of the sediment or mentioned in the lithologic description.

\section{Induration of Sediments}

We recognize three classes of induration or lithification for calcareous sediments and sedimentary rocks (sediments and rocks in which the carbonate content is greater than $50 \%$ ) and only two classes for all other lithologic types.

1. Calcareous sediments and sedimentary rocks (categories after Gealy et al., 1971):

a. Soft $=$ ooze; has little strength and is readily deformed under the pressure of a finger or the broad blade of a spatula.

b. Firm = chalk; partially lithified and readily scratched with a fingernail or the edge of spatula.

c. Hard = limestone; or dolostone; well lithified and cemented, resistant or impossible to scratch with a fingernail or the edge of a spatula.

2. Siliceous sediments (silica $>50 \%$ ):

a. Soft $=$ ooze; readily deformed by a finger or the broad blade of a spatula.

b. Hard = radiolarite, diatomite, chert, or porcellanite; core must be cut with a band saw or a diamond saw.

3. Terrigenous sediments (terrigenous components $>50 \%$ ):

a. Soft $=$ sand, silt, clay (or combinations of these); readily deformed by a finger or the broad blade of a spatula.

b. Hard = sandstone, siltstone, claystone, etc. (i.e., suffix "stone" added); core must be cut with a band saw or a diamond saw.

\section{Types of Sediment and Compositional Class Boundaries}

We distinguish six basic types of sediment: siliceous biogenic sediments, calcareous biogenic sediments, terrigenous sediments, volcanogenic and pyroclastic sediments, hemipelagic sediments, and pelagic clay. Each type of sediment is discussed briefly below. Only siliceous biogenic sediments, hemipelagic sediments, and pelagic clay were cored during Legs 88 and 91.

\section{Siliceous Biogenic Sediments}

These are sediments in which biogenic silica or authigenic silica (opal-CT and/or quartz) makes up at least $30 \%$ of the sediment. If the siliceous component is between 30 and $60 \%$, the terrigenous (mud) calcareous biogenic or volcanogenic modifier is retained. For example, muddy diatomaceous ooze describes a soft sediment with at least $10 \%$ clayey silt and between 50 and $90 \%$ diatoms. If the siliceous component exceeds $60 \%$, the modifier(s) are dropped. A radiolarian ooze would have $<10 \%$ clay or carbonate and $>60 \%$ radiolarians. If the siliceous biogenic component is between 30 and $60 \%$, the names for terrigenous or calcareous biogenic sediments or pyroclastic rocks apply, with the dominant siliceous constituent as a qualifier. Silica in amounts $<10 \%$ is not acknowledged in the name.

For hard siliceous rocks, siliceous microfossils are often absent. If they have been dissolved and replaced by opal-CT and/or quartz and these minerals make up $>50 \%$ of the rock, the terms chert and porcellanite apply. Chert is defined as a hard, conchoidally fractured varicolored sedimentary rock that has a semivitreous, 
vitreous, or waxy luster and that consists primarily of silica. Porcellanite is defined as a siliceous sedimentary rock that has a dull or matte luster that resembles that of unglazed porcelain. It is less hard, dense, and vitreous than chert and commonly has a lower silica content. These definitions differ from previous DSDP usage in that chert and porcellanite are textural terms independent of the silica polymorphy present. If two modifiers are used, the order of the two modifiers in the terms depends on the dominant fossil type. The most dominant component is listed last and the minor component is listed first.

\section{Hemipelagic Sediments}

Sediments with $>75 \%$ clay and $<25 \%$ radiolarians plus diatoms were recovered during Leg 88 . These are termed siliceous clay and biosiliceous clay.

\section{Pelagic Clay}

Pelagic clay is authigenic material that accumulated at a very slow rate. The terms brown clay or red clay are often used synonymously with pelagic clay, but not here.

Pelagic clay was the principal sediment type recovered during Leg 91 . The sediments carry abundant particles of red-brown to yellow-brown semi-opaque oxides (RSOs) reflecting an unusually high metalliferous component, even for pelagic clays, and in fact grade compositionally to metalliferous clay of the type usually found above basalts and listed as a special sediment category in previous DSDP sediment classification schemes. Here, we use the following definitions to specify this gradation.

1) RSOs $<30 \%$ - pelagic clay, no modifier

2) $30 \%<$ RSOs $<60 \%$ - metalliferous pelagic clay

3) $60 \%<$ RSOs-metalliferous clays

We have also indicated the presence of RSOs and zeolites by addition of two symbols to the graphic lithology column (Fig. 9).

\section{Other Sediments}

No calcareous biogenic, terrigenous, volcanogenic, or pyroclastic sediments were recovered during either Leg 88 or Leg 91 .

\section{Special Studies of Sediments}

\section{Biostratigraphy}

No biostratigraphic determinations were made on the few sediment cores obtained during Leg 88 .

Biostratigraphy for Leg 91 sediments is based on ichthyoliths (fish teeth) only, as described in Winfrey et al. (this volume).

\section{Igneous Rocks}

\section{Visual Core Description Forms}

All igneous rocks were split by using a rock saw into working and archive halves and described on board. Figure 11 shows a composite visual core description form used for the description of the igneous rocks. Each section of core is described on this form under five col-

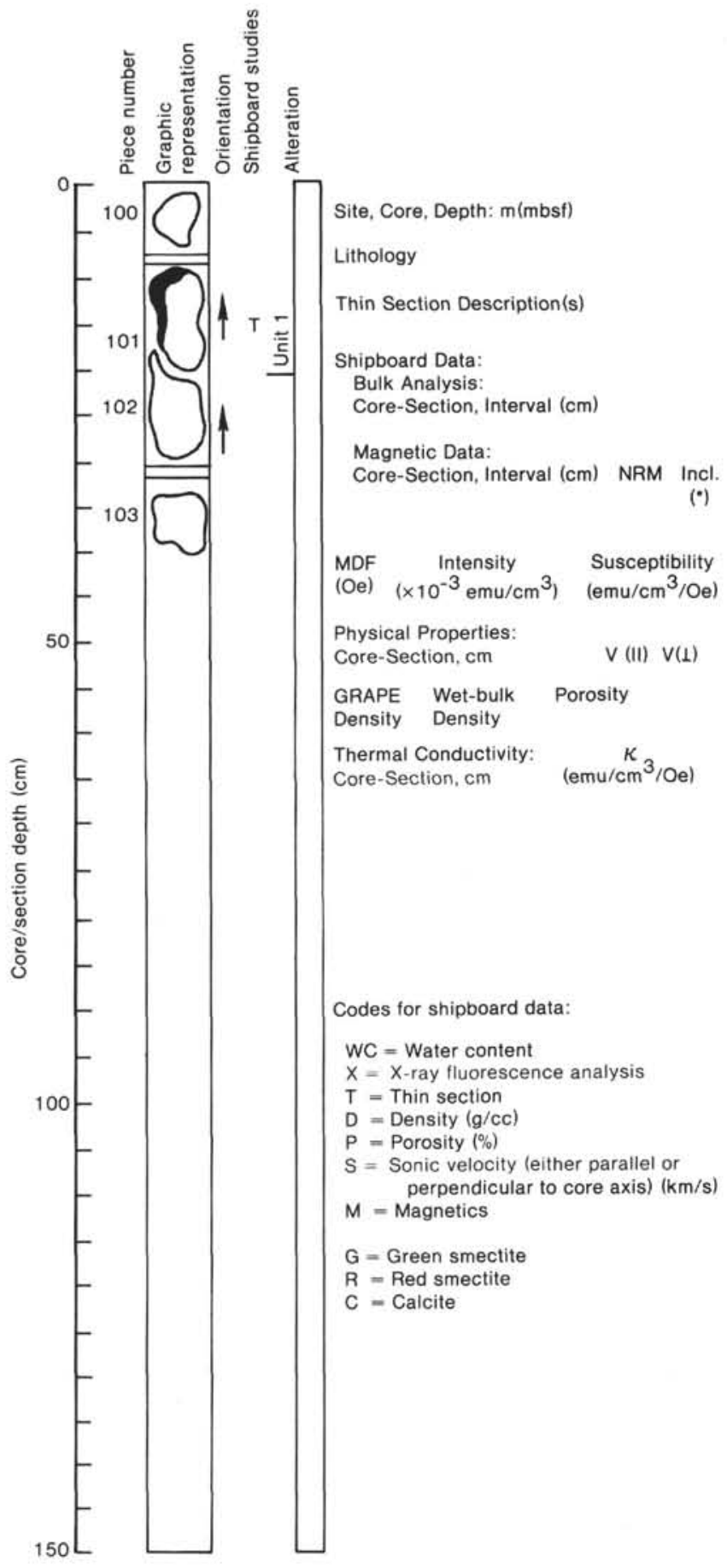

Figure 11. Visual core description form for igneous rocks.

umns: piece number, graphic representation, orientation, shipboard studies, and alteration.

In the graphic representation column, each piece is accurately drawn, as well as such features as texture, glassy margins, and the location of styrofoam spacers taped between pieces inside the liner. Each piece is numbered consecutively from the top of each section, beginning with the number 1 . Pieces which are broken, but fit together are labeled with an additional letter sequentially downsection as 1A, 1B, 1C, etc. Spacers separate pieces 
with different numbers but not different letters. Spacers may or may not indicate missing material (not recovered) between pieces. All cylindrical pieces longer than the diameter of the liner have arrows in the "orientation" column indicating that top and bottom could not have been reversed as a result of drilling recovery. Arrows also appear on the labels of these pieces on both archive and working halves.

The column marked "Shipboard Studies" is used to indicate the location and the type of measurements made on a sample on board. The column headed "Alteration" gives the degree of alteration by using the code given in Figure 12. Below each set of five columns is the designation for core and section for which the data apply.
An outline of further information on the igneous rocks appears in the right-hand margin of the visual core description form (Fig. 11). For each core, the core number, sections, and depth interval recovered are listed, followed by the major and minor rock types and a short description. Thin section data are tallied below this, then shipboard data. If more than one core appears on a single core form some of the information is listed below the description of the first core. As many cores as space allows are included on one visual core description form. When space for descriptions is inadequate on this form, the data appear on the following or facing page. However, in no case does information from one core appear on more than one core form.

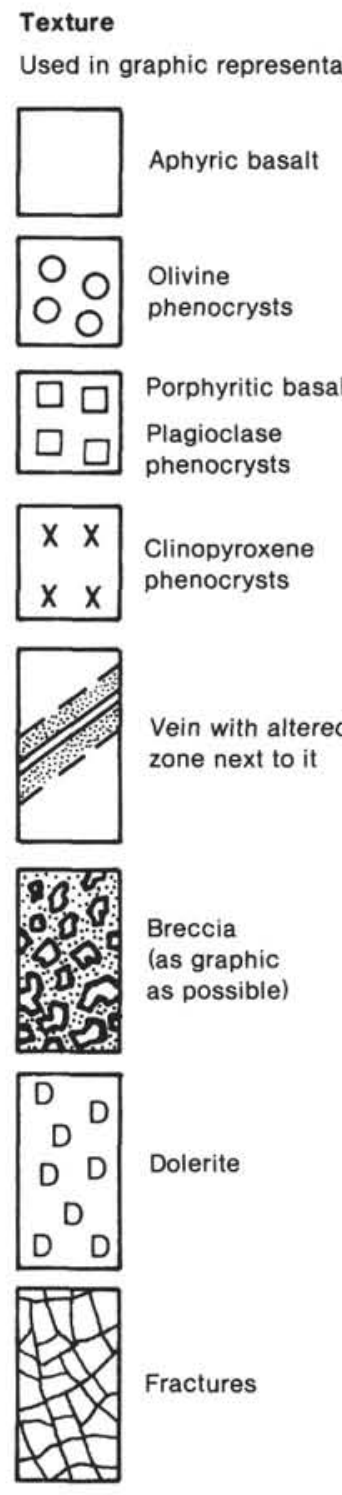

Weathering: alteration

Used in alteration column

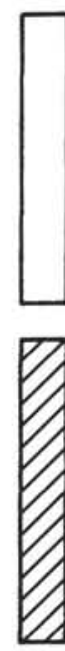

Moderately altered

Badly

altered

Almost completely altered

Moderately altered (slight discoloration) but has fresh core or is partly fresh

Figure 12. Symbols used to describe igneous rocks. 
Because alteration minerals were abundant, we indicated their occurrence and type based on color by using the letter G (green), B (black), or R (red) immediately to the right of the alteration column. Carbonate minerals (calcite, aragonite) are indicated by the letter C.

\section{Classification of Igneous Rocks}

We classified igneous rocks informally according to mineralogy and texture as determined from the visual inspection of hand specimens and thin sections. Basalts cored during Legs 88 and 91 are aphyric to very sparsely phyric, hence are simply termed basalts. Other descriptions, such as massive, variolitic, and glassy, were used as necessary. The characteristics of variolitic zones were useful in defining lithologic (chemical) types. Thin sections to determine the presence or absence of olivine were also used.

\section{REFERENCES}

Adair, R. G., Orcutt, J. A., and Jordan, T. H., 1984. Analysis of ambient seismic noise recorded by downhole and ocean-bottom seismometers on Deep Sea Drilling Project Leg 78B. In Hyndman, R. D., Salisbury, M. H., et al., Init. Repts. DSDP, 78B: Washington (U.S. Govt. Printing Office), 767-781.

Ballard, J. A., Mulcahy, C. C., Wallerstedt, R. L., and Kiser, E. L., 1984. The borehole seismic experiment in Hole 395A: Engineering and installation. In Hyndman, R. D., Salisbury, M. H., et al, Init. Repts. DSDP, 78B: Washington (U.S. Govt. Printing Office), 743757.

Bradner, H., Dedds, J. G., and Foulks, R. E., 1965. Coherence measurements with time sampling ocean-bottom seismometers. Proc. I.E.E.E., 53:1906-1908.

Burns, R. E., Andrews, J. E., et al., 1973. Init. Repts. DSDP, 21: Washington (U.S. Govt. Printing Office).
Garmany, J., 1984. The recovery of the true particle motion from threecomponent ocean-bottom seismometer data. J. Geophys. Res., 89: 9245-9252.

Gealy, E. L., Winterer, E. L., and Moberly, R. M., 1971. Methods, conventions, and general observations. In Winterer, E. L., Riedel, W. R., et al., Init. Repts. DSDP, 7, Pt. 1: Washington (U.S. Govt. Printing Office), 9-26.

Houtz, R. E., and Ludwig, W. J., 1979. Distribution of reverberant subbottom layers in the southwest Pacific Basin. J. Geophys. Res., 84:3497-3504.

Jacobson, R. S., Adair, R. G., and Orcutt, J. A., 1984. Preliminary seismic refraction results using a borehole seismometer in Deep Sea Drilling Project Hole 395A. In Hyndman, R. D., Salisbury, M. H., et al., Init. Repts. DSDP, 78B: Washington (U.S. Govt. Printing Office), 783-792.

Latham, G. V., and Nowroozi, A. A., 1968. Waves, weather, and oceanbottom microseisms. J. Geophys. Res., 73:3945-3956.

Latham, G. V., and Sutton, G. H., 1966. Seismic measurements on the ocean floor, 1. Bermuda area. J. Geophys. Res., 71:2545-2572.

Natland, J. H., and Rosendahl, B. R., 1980. Drilling difficulties in basement during Deep Sea Drilling Project Leg 54. In Rosendahl, B. R., Hekinian, R., et al., Init. Repts. DSDP, 54: Washington (U.S. Govt. Printing Office), 593-603.

Ross, D. A., Neprochnov, Y., et al., 1978. Init. Repts. DSDP, 42: Washington (U.S. Govt. Printing Office).

Shipboard Scientific Party, 1976. Preliminary evaluation of DSDP coring experience in basalt, Leg 34. In Yeats, R. S., Hart, S. R., et al., Init. Repts. DSDP, 34: Washington (U.S. Govt. Printing Office), 183-186.

Sutton, G. H., Duennebier, F. K., and Iwatake, B., 1981. Coupling of ocean-bottom seismometers to soft bottom. Mar. Geophys. Res., 5:35-51.

Sutton, G. H., Lewis, B. T. R., Ewing, J., Duennebier, F. K., Iwatake, B., and Tuthill, J. D., 1980. Lopez Island ocean-bottom seismometer intercomparison experiment. Hawaii Inst. of Geophys. Contrib. 80-4:1-72.

Zelikovitz, S. J., and Prothero, W. A., 1981. The vertical response of an ocean-bottom seismometer: Analysis of Lopez Island vertical transient test. Mar. Geophys. Res., 5:53-67. 